\title{
Golden Eggs and Hyperbolic Discounting
}

\section{Citation}

David Laibson. 1997. Golden eggs and hyperbolic discounting. Quarterly Journal of Economics 112(2): 443-477.

\section{Published Version}

http://dx.doi.org/10.1162/003355397555253

\section{Permanent link}

http://nrs.harvard.edu/urn-3:HUL.InstRepos:4481499

\section{Terms of Use}

This article was downloaded from Harvard University's DASH repository, and is made available under the terms and conditions applicable to Other Posted Material, as set forth at http:// nrs.harvard.edu/urn-3:HUL.InstRepos:dash.current.terms-of-use\#LAA

\section{Share Your Story}

The Harvard community has made this article openly available.

Please share how this access benefits you. Submit a story.

\section{Accessibility}




\title{
GOLDEN EGGS AND HYPERBOLIC DISCOUNTING*
}

\author{
DAVID LAIBSON
}

Hyperbolic discount functions induce dynamically inconsistent preferences, implying a motive for consumers to constrain their own future choices. This paper analyzes the decisions of a hyperbolic consumer who has access to an imperfect commitment technology: an illiquid asset whose sale must be initiated one period before the sale proceeds are received. The model predicts that consumption tracks income, and the model explains why consumers have asset-specific marginal propensities to consume. The model suggests that financial innovation may have caused the ongoing decline in U. S. savings rates, since financial innovation increases liquidity, eliminating commitment opportunities. Finally, the model implies that financial market innovation may reduce welfare by providing "too much" liquidity.

\section{INTRODUCTION}

"Use whatever means possible to remove a set amount of money from your bank account each month before you have a chance to spend it"

$$
\text { —advice in New York Times "Your Money" column [1993]. }
$$

Many people place a premium on the attribute of self-control. Individuals who have this capacity are able to stay on diets, carry through exercise regimens, show up to work on time, and live within their means. Self-control is so desirable that most of us complain that we do not have enough of it. Fortunately, there are ways to compensate for this shortfall. One of the most widely used techniques is commitment. For example, signing up to give a seminar is an easy way to commit oneself to write a paper. Such commitments matter since they create constraints (e.g., deadlines) that generally end up being binding.

Strotz [1956] was the first economist to formalize a theory of commitment and to show that commitment mechanisms could be potentially important determinants of economic outcomes. He

*This work has been supported financially by the National Science Foundation (SBR-95-10985) and the Alfred P. Sloan Foundation. I am grateful to Olivier Blanchard for posing the questions that motivated this paper. I have also benefited from the insights of Roland Bénabou, Ricardo Caballero, Robert Hall, Matthew Rabin, an anonymous referee, and seminar participants at the University of California at Berkeley, Boston University, the University of Chicago, Harvard University, the Massachusetts Institute of Technology, Northwestern University, Princeton University, Stanford University, and the University of Pennsylvania. Joshua S. White provided excellent research assistance. All mistakes should be blamed on my $t-1$ period self.

(C) 1997 by the President and Fellows of Harvard College and the Massachusetts Institute of Technology.

The Quarterly Journal of Economics, May 1997. 
showed that when individuals' discount functions are nonexponential, they will prefer to constrain their own future choices. Strotz noted that costly commitment decisions are commonly observed:

... we are often willing even to pay a price to precommit future actions (and to avoid temptation). Evidence of this in economic and other social behaviour is not difficult to find. It varies from the gratuitous promise, from the familiar phrase "Give me a good kick if I don't do such and such" to savings plans such as insurance policies and Christmas Clubs which may often be hard to justify in view of the low rates of return. (I select the option of having my annual salary dispersed to me on a twelve- rather than on a nine-month basis, although I could use the interest!) Personal financial management firms, such as are sometimes employed by high-income professional people (e.g. actors), while having many other and perhaps more important functions, represent the logical conclusion of the desire to precommit one's future economic activity. Joining the army is perhaps the supreme device open to most people, unless it be marriage for the sake of "settling down." The worker whose income is garnished chronically or who is continually harassed by creditors, and who, when one oppressive debt is paid, immediately incurs another is commonly precommiting. There is nothing irrational about such behavior (quite the contrary) and attempts to default on debts are simply the later consequences which are to be expected. Inability to default is the force of the commitment.

Strotz's list is clearly not exhaustive. In general, all illiquid assets provide a form of commitment, though there are sometimes additional reasons that consumers might hold such assets (e.g., high expected returns and diversification). A pension or retirement plan is the clearest example of such an asset. Many of these plans benefit from favorable tax treatment, and most of them effectively bar consumers from using their savings before retirement. For IRAs, Keogh plans, and 401(K) plans, consumers can access their assets, but they must pay an early withdrawal penalty. Moreover, borrowing against some of these assets is legally treated as an early withdrawal, and hence also subject to penalty. A less transparent instrument for commitment is an investment in an illiquid asset that generates a steady stream of benefits, but that is hard to sell due to substantial transactions costs, informational problems, or incomplete markets. Examples 
include purchasing a home, buying consumer durables, and building up equity in a personal business. Finally, there exists a class of assets that provide a store of illiquid value, like savings bonds, and certificates of deposit. All of the illiquid assets discussed above have the same property as the goose that laid golden eggs. The asset promises to generate substantial benefits in the long run, but these benefits are difficult, if not impossible, to realize immediately. Trying to do so will result in a substantial capital loss.

Instruments with these golden eggs properties make up the overwhelming majority of assets held by the U. S. household sector. For example, the Federal Reserve System publication Balance Sheets for the U. S. Economy 1945-94 reports that the household sector held domestic assets of $\$ 28.5$ trillion at yearend 1994. Over two-thirds of these assets were illiquid, including $\$ 5.5$ trillion of pension fund and life insurance reserves, $\$ 4.5$ trillion of residential structures, $\$ 3.0$ trillion of land, $\$ 2.5$ trillion of equity in noncorporate business, $\$ 2.5$ trillion of consumer durables, and at least $\$ 1$ trillion of other miscellaneous categories. Finally, note that social security wealth and human capital, two relatively large components of illiquid wealth, are not included in the Federal Reserve Balance Sheets.

Despite the abundance of commitment mechanisms, and Strotz's well-known theoretical work, intrapersonal commitment phenomena have generally received little attention from economists. This deficit is probably explained by the fact that commitment will only be chosen by decision-makers whose preferences are dynamically inconsistent, and most economists have avoided studying such problematic preferences. However, there is a substantial body of evidence that preferences are dynamically inconsistent. Research on animal and human behavior has led psychologists to conclude that discount functions are approximately hyperbolic [Ainslie 1992].

Hyperbolic discount functions are characterized by a relatively high discount rate over short horizons and a relatively low discount rate over long horizons. This discount structure sets up a conflict between today's preferences, and the preferences that will be held in the future. For example, from today's perspective, the discount rate between two far-off periods, $t$ and $t+1$, is the long-term low discount rate. However, from the time $t$ perspective, the discount rate between $t$ and $t+1$ is the short-term high 
discount rate. This type of preference change is reflected in many common experiences. For example, this year I may desire to start an aggressive savings plan next year, but when next year actually rolls around, my taste at that time will be to postpone any sacrifices another year. In the analysis that follows, the decisionmaker foresees these conflicts and uses a stylized commitment technology to partially limit the options available in the future.

This framework predicts that consumption will track income. Second, the model explains why consumers have a different propensity to consume out of wealth than they do out of labor income. Third, the model explains why Ricardian equivalence should not hold even in an economy characterized by an infinitely lived representative agent. Fourth, the model suggests that financial innovation may have caused the ongoing decline in U. S. savings rates, since financial innovation increases liquidity and eliminates implicit commitment opportunities. Finally, the model provides a formal framework for considering the proposition that financial market innovation reduces welfare by providing "too much" liquidity.

The body of this essay formalizes these claims. Section II lays out the model. Equilibrium outcomes are characterized in Section III. Section IV considers the implications of the model for the macroeconomic issues highlighted above. Section V concludes with a discussion of ongoing work.

\section{The Consumption Decision}

The large number of commitment devices, discussed above, is good news for consumers. They have access to a wide array of assets that effectively enable them to achieve many forms of commitment. However, from the perspective of an economist, the abundance poses a challenge. It is hard to model the institutional richness in a realistic way without generating an extremely burdensome number of state variables.

I consider a highly stylized commitment technology that is amenable to an analytic treatment. Specifically, I assume that consumers may invest in two instruments: a liquid asset $x$ and an illiquid asset $z$. Instrument $z$ is illiquid in the sense that a sale of this asset has to be initiated one period before the actual proceeds are received. So a current decision to liquidate part or all of an individual's $z$ holding will generate cash flow that can be 
consumed no earlier than next period. ${ }^{1}$ By contrast, agents can always immediately consume their $x$ holdings.

Consumers in this model may borrow against their holdings of asset $z$. Like asset sales, such borrowing takes one period to implement. If a consumer applies for a loan at time period $t$, the associated cash flow will not be available for consumption until time period $t+1$.

In later sections I embed consumers in a general equilibrium model in which prices will be endogenous. Now, however, I consider the consumer in isolation, and assume that the consumer faces a deterministic sequence of interest rates and wages. For simplicity, I assume that asset $z$ and asset $x$ have the same rate of return. ${ }^{2}$

The consumer makes consumption/savings decisions in discrete time $t \in\{1,2, \ldots, T\}$. Every time period $t$ is divided into four subperiods. In the first subperiod, production takes place. The consumer's liquid assets $x_{t-1}$ and nonliquid assets $z_{t-1}$-both chosen at time period $t-1$-yield a gross return of $R_{t}=1+r_{t}$, and the consumer inelastically supplies one unit of labor. In the second subperiod the consumer receives deterministic labor income $y_{t}$ and gets access to her liquid savings, $R_{t} \cdot x_{t-1}$. In the third subperiod the consumer chooses current consumption,

$$
c_{t} \leq y_{t}+R_{t} x_{t-1} .
$$

In the fourth subperiod the consumer chooses her new asset allocations, $x_{t}$ and $z_{t}$, subject to the constraints,

$$
\begin{gathered}
y_{t}+R_{t}\left(z_{t-1}+x_{t-1}\right)-c_{t}=z_{t}+x_{t}, \\
x_{t}, z_{t} \geq 0 .
\end{gathered}
$$

The consumer begins life with exogenous endowments $x_{0}, z_{0} \geq 0$.

The consumer may borrow against her illiquid assets by giving a creditor a contingent control right over some of those assets. In exchange, the consumer receives liquidity that can be consumed. Such a loan is formally represented as a reallocation of assets from the illiquid account to the liquid account. I assume that a loan, i.e., asset reallocation, which generates consumable liquidity in period $t+1$ must be initiated in period $t$. Specifically,

1. One could alternatively assume that instantaneous access to asset $z$ is possible with a sufficiently high transaction cost.

2 . The qualitative results do not hinge on the identical returns assumption. 
the asset reallocation occurs in subperiod 4 of period $t$, thereby providing consumable liquidity in period $t+1$. Such asset reallocations are subsumed in the consumer's choice of $x_{t}$ and $z_{t}$ in subperiod 4.

In the framework introduced above, an uncollateralized loan has occurred if an asset reallocation leaves the illiquid account negative. Creditors are unwilling to make such loans because a consumer who received such a loan would not have an incentive to repay. Hence, I assume that $z_{t} \geq 0$.

Finally, the constraint $x_{t} \geq 0$ rules out forced savings contracts. If the consumer could set $x_{t}$ to any negative value, then she could perfectly commit her future savings behavior and hence her consumption level (or at least commit to any upper bound on tomorrow's consumption level). For example, if she foresaw a high level of labor income next period, she could set $x_{t}$ negative to force tomorrow's self to save some of that income (recall that $c_{t+1} \leq y_{t+1}+R_{t+1} x_{t}$ ). A negative $x_{t}$ value would be interpreted as a contract with an outside agent requiring the consumer to transfer funds to the outside agent, which the outside agent would then deposit in an illiquid account of the consumer. ${ }^{3}$ The constraint $x_{t}$ $\geq 0$ effectively rules out such contracts. Two arguments support this implicit assumption against forced savings contracts.

First, such contracts are susceptible to renegotiation by tomorrow's self, and in any finite-horizon environment, the contract would unwind. (In the second to last period renegotiation would occur, implying renegotiation in the third to last period, etc.) Second, such contracts are generally unenforceable in the United States. ${ }^{4}$ To make such a contract work, tomorrow's self must be forced to pay the specified funds to the outside agent or be penalized for not doing so (note that the transfer is not in the interest of tomorrow's self). However, U. S. courts will generally not enforce contracts with a penalty of this kind. ${ }^{5}$

3. Mortgage payments are an example of a contract that $x_{t} \geq 0$ rules out. However, even though mortgage payments may be interpreted as forced savings contracts, they do not have the necessary flexibility to achieve the full commitment solution. Mortgage contracts generally do not make mortgage payments contingent on the level of labor income flows.

4. I am indebted to Robert Hall for pointing out this fact to me.

5. U. S. contract law is based around the "fundamental principle that the law's goal on breach of contract is not to deter breach by compelling the promisor to perform, but rather to redress breach by compensating the promisee" [Farnsworth 1990 , p. 935]. Hence, courts allow contracts to specify "liquidated damages" which reflect losses likely to be experienced by the promisee, but courts do not allow "penalties" which do not reflect such losses. 
At time $t$, the consumer has a time-additive utility function $U_{t}$ with an instantaneous utility function characterized by constant relative risk aversion $\rho$. Consumers are assumed to have a discount function of the type proposed by Phelps and Pollak [1968] in a model of intergenerational altruism, and which is used here to model intrapersonal dynamic conflict: ${ }^{6}$

$$
U_{t}=E_{t}\left[u\left(c_{t}\right)+\beta \sum_{\tau=1}^{T-t} \delta^{\tau} u\left(c_{t+\tau}\right)\right]
$$

I adopt equation (1) to capture the qualitative properties of a generalized hyperbolic discount function: events $\tau$ periods away are discounted with factor $(1+\alpha \tau)^{-\gamma / \alpha}$, with $\alpha, \gamma>0 .{ }^{7}$ This class of discount functions was first proposed by Chung and Herrnstein [1961] to characterize the results of animal behavior experiments. ${ }^{8}$ Their conclusions were later shown to apply to human subjects as well (see Ainslie [1992] for a survey).

Hyperbolic discount functions imply discount rates that decline as the discounted event is moved further away in time [Loewenstein and Prelec 1992]. Events in the near future are discounted at a higher implicit discount rate than events in the distant future.

Given a discount function $f(\tau)$, the instantaneous discount rate at time $\tau$ is defined as

Applying the principle of 'just compensation for the loss or injury actually sustained' to liquidated damage provisions, courts have ... refused enforcement where the clause agreed upon is held to be in terrorem-a sum fixed as a deterrent to breach or as security for full performance by the promisor, not as a realistic assessment of the provable damage. Thus, attempts to secure performance through in terrorem clauses are currently declared unenforceable even where the evidence shows a voluntary, fairly bargained exchange [Goetz and Scott 1977, p. 555].

In our case, the promisee-the outside agent-experiences no loss if the consumer fails to make the payment. Hence, penalties or liquidated damages specified in such contracts are not enforceable, so the contract is incapable of compelling tomorrow's self to make the payment. For a more extensive discussion of these issues, see Farnsworth [1990, pp. 935-46], Goetz and Scott [1977], and Rea [1984].

6. Zeckhauser and Fels [1968] provide an altruism-based microfoundation for the Phelps and Pollak preferences. Akerlof [1991] analyzes a special case of the Phelps and Pollak preferences $(\delta=1)$. Akerlof assumes consumer myopia, while my analysis assumes that consumers foresee their future preference reversals.

7. See Loewenstein and Prelec [1992] for an axiomatic derivation of this discount function.

8. Chung and Herrnstein claimed that the appropriate discount function is an exact hyperbola: events $\tau$ periods away are discounted with factor $1 / \tau$. This corresponds to the limiting case $\alpha=\gamma \rightarrow \infty$. 


$$
-f^{\prime}(\tau) / f(\tau) .
$$

Hence, an exponential discount function, $\delta^{\tau}$ is characterized by a constant discount rate, $\log (1 / \delta)$, while the generalized hyperbolic discount function is characterized by an instantaneous discount rate that falls as $\tau$ rises:

$$
\gamma /(1+\alpha \tau)
$$

Psychologists and economists-notably Ainslie [1975, 1986, 1992], Prelec [1989], and Loewenstein and Prelec [1992]—have argued that such declining discount rates play an important role in generating problems of self-regulation.

When $0<\beta<1$, the discount structure in equation (1) mimics the qualitative property of the hyperbolic discount function, while maintaining most of the analytical tractibility of the exponential discount function. I call the discount structure in equation (1) "quasi-hyperbolic." Note that the quasi-hyperbolic discount function is a discrete time function with values $\{1, \beta \delta$, $\left.\beta \delta^{2}, \beta \delta^{3}, \ldots\right\}$. Figure I graphs the exponential discount function (assuming that $\delta=0.97$ ), the generalized hyperbolic discount function (assuming that $\alpha=10^{5}$, and $\gamma=5 \cdot 10^{3}$ ), and the quasihyperbolic discount function (with $\beta=0.6$ and $\delta=0.99$ ). The

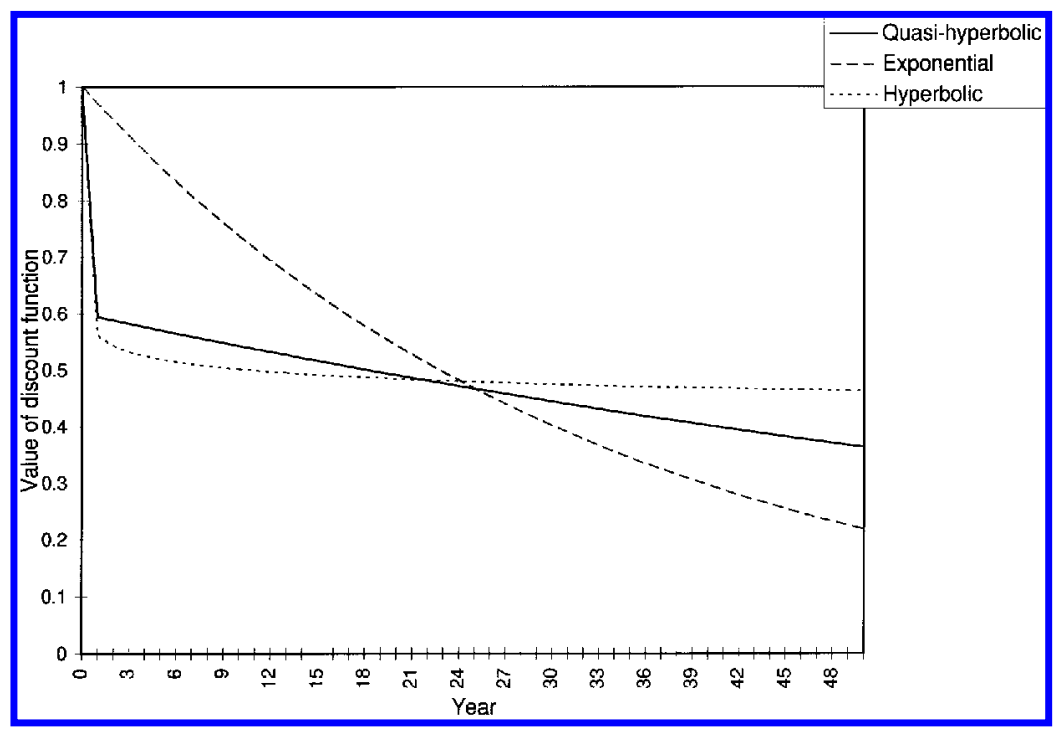

Figure I

Discount Functions 
points of the discrete-time quasi-hyperbolic function have been connected to generate the curve in Figure I.

The preferences given by equation (1) are dynamically inconsistent, in the sense that preferences at date $t$ are inconsistent with preferences at date $t+1$. To see this, note that the marginal rate of substitution between periods $t+1$ and $t+2$ from the perspective of the decision-maker at time $t$ is given by $u^{\prime}\left(c_{t+1}\right) /\left(\delta u^{\prime}\left(c_{t+2}\right)\right)$, which is not equal to the marginal rate of substitution between those same periods from the perspective of the decision-maker at $t+1: u^{\prime}\left(c_{t+1}\right) /\left(\beta \delta u^{\prime}\left(c_{t+2}\right)\right)$.

To analyze equilibrium behavior when preferences are dynamically inconsistent, it is standard practice to formally model a consumer as a sequence of temporal selves making choices in a dynamic game (e.g., Pollak [1968], Peleg and Yaari [1973], and Goldman [1980]). Hence, a T-period consumption problem translates into a $T$-period game, with $T$ players, or "selves," indexed by their respective periods of control over the consumption decision. (Note that self $t$ is in control during all of the subperiods at time $t$.) I look for subgame perfect equilibrium (SPE) strategies of this game.

It is helpful to introduce some standard notation that will be used in the analysis which follows. Let $h_{t}$ represent a (feasible) history at time $t$, so $h_{t}$ represents all the moves that have been made from time 0 to time $t-1:\left\{x_{0}, z_{0},\left(c_{\tau}, x_{\tau}, z_{\tau}\right)_{\tau=1}^{t-1}\right\}$. Let $S_{t}$ represent the set of feasible strategies for self $t$. Let $S=\Pi_{t=1}^{T} S_{t}$ represent the joint strategy space of all selves. If $s \in S$, let $s \mid h_{t}$ represent the path of consumption and asset allocation levels from $t$ to $T$ which would arise if history $h_{t}$ were realized, and selves $t$ to $T$ played the strategies given by $s$. Finally, let $U_{t}\left(s \mid h_{t}\right)$ represent the continuation payoff to self $t$ if self $t$ expects the consumption and asset allocation levels from $t$ to $T$ to be given by $s \mid h_{t}$.

\section{Equilibrium Strategies}

This section characterizes the equilibrium strategies of the game described above. Recall that the agent faces a deterministic (time-varying) sequence of interest rates and a deterministic (time-varying) labor income sequence. Unfortunately, for general interest rate and labor income sequences, it is not possible to use marginal conditions to characterize the equilibrium strategies. This nonmarginality property is related to the fact that selves who make choices at least two periods from the end of the game 
face a nonconvex reduced-form choice set, where the reducedform choice set is defined as the consumption vectors which are attainable, assuming that all future selves play equilibrium strategies. The nonconvexity in the reduced-form choice set of self $T-2$ generates discontinuous equilibrium strategies for self $T-2$, which in turn generate discontinuities in the equilibrium payoff map of self $T-3$. This implies that marginal conditions cannot be used to characterize the equilibrium choices of selves at least three periods from the end of the game. ${ }^{9}$

I have found a restriction on the labor income process that eliminates these problems:

$$
u^{\prime}\left(y_{t}\right) \geq \beta \delta^{\tau}\left(\prod_{i=1}^{\tau} R_{t+i}\right) u^{\prime}\left(y_{t+\tau}\right) \quad \forall t, \tau \geq 1 .
$$

This restriction constrains the sequence $\left\{y_{t}\right\}_{t=1}^{t=T}$ to lie in a band whose thickness is parameterized by the value of $\beta$; the closer $\beta$ is to zero, the wider the band. Calibration of the model reveals that A1 allows for substantial flexibility in the deterministic income process. Ainslie [1992] reviews evidence that the one-year discount rate is at least $1 / 3$. This suggests that $\beta$ should be calibrated in the interval $(0,2 / 3)$ (assuming that $\delta$ is close to unity). To see what this implies, consider the following example. Assume that $R_{t}=R$ for all $t, \delta R=1$, and $u(\cdot)=\ln (\cdot)$. Then $\mathrm{A} 1$ is satisfied if, for all $t, y_{t} \in[y,(1 / \beta) y]$. If $\beta=2 / 3$, this interval becomes [ $y$, (3/ $2) y$, and as $\beta$ falls the interval grows even larger.

Before characterizing the equilibria of the game, it is helpful to introduce the following definitions. First, we will say that a joint strategy, $s$, is resource exhausting if $s \mid h_{T-1}$ is characterized by $z_{T}=x_{t}=0$, for all feasible $h_{T-1}$. Second, we will say that a sequence of feasible consumption/savings actions, $\left\{c_{\hat{t}}, x_{\hat{t}}, z_{\hat{t}}, \ldots\right.$, $\left.c_{T}, \mathrm{x}_{T}, \mathrm{z}_{T}\right\}$ satisfies P1-P4 if $\forall t \geq \hat{t}$,

$$
\begin{aligned}
& \text { P1 } u^{\prime}\left(c_{t}\right) \geq \max _{\tau \in\{1, \ldots, T-t\}} \beta \delta^{\tau}\left(\prod_{i=1}^{\tau} R_{t+i}\right) u^{\prime}\left(c_{t+\tau}\right) \\
& \text { P2 } u^{\prime}\left(c_{t}\right)>\max _{\tau \in\{1, \ldots, T-t\}} \beta \delta^{\tau}\left(\prod_{i=1}^{\tau} R_{t+i}\right) u^{\prime}\left(c_{t+\tau}\right) \Rightarrow c_{t}=y_{t}+R_{t} x_{t-1} \\
& \text { P3 } u^{\prime}\left(c_{t+1}\right)<\max _{\tau \in\{1, \ldots, T-t-1\}} \delta^{\tau}\left(\prod_{i=1}^{\tau} R_{t+i}\right) u^{\prime}\left(c_{t+1+\tau}\right) \Rightarrow x_{t}=0 \\
& \text { P4 } u^{\prime}\left(c_{t+1}\right)>\max _{\tau \in\{1, \ldots, T-t-1\}} \delta^{\tau}\left(\prod_{i=1}^{\tau} R_{t+i}\right) u^{\prime}\left(c_{t+1+\tau}\right) \Rightarrow z_{t}=0 .
\end{aligned}
$$

9. For an exposition of these problems see Laibson [1993]. Related issues are also discussed in Peleg and Yaari [1973] and Goldman [1980]. 
Finally, we will say that a joint strategy $s \in S$ satisfies $\mathrm{P} 1-\mathrm{P} 4$ if for any feasible history $h_{\hat{t}}, s \mid h_{\hat{t}}$ satisfies P1-P4.

It is now possible to state the main theorem of the paper. This theorem establishes that the consumption game has a unique equilibrium, and the theorem characterizes this equilibrium.

Theorem 1. Fix any T-period consumption game with exogenous variables satisfying A1. There exists a unique resourceexhausting joint strategy, $s^{*} \in S$, that satisfies $\mathrm{P} 1-\mathrm{P} 4$, and this strategy is the unique subgame perfect equilibrium strategy of this game.

(All proofs appear in the Appendix.) Theorem 1 implies that the equilibrium consumption path is resource exhausting and satisfies P1-P4. It is straightforward to see why the equilibrium path is resource exhausting: the final self-self $T$-consumes all liquid resources in period $T$, and self $T-1$ makes certain that all wealth is liquid in period $T$ (i.e., $z_{T-1}=0$ ). Hence, no wealth goes unconsumed in equilibrium.

Properties $\mathrm{P} 1-\mathrm{P} 4$ are also intuitive. It is important to interpret them in light of the strategic self-control behavior that arises in the intrapersonal consumption game. In this game, early selves prevent late selves from splurging. Self $t-1$ uses the illiquid asset $z_{t-1}$ to limit the liquidity available for consumption in period $t$. Note that self $t$ cannot consume the illiquid asset during its period of control, $c_{t} \leq y_{t}+R_{t} x_{t-1}$. On the equilibrium path, each self is endogenously liquidity constrained by the allocation choices of earlier selves. Property P1 is simply a standard Euler equation relation for an environment in which liquidity constraints exist. The inequality arises because marginal utility can be too high relative to future marginal utilities, but it cannot be too low since consumers always have the option to save. Property P2 reflects another standard Euler equation intuition: when marginal utility is strictly too high, the liquidity constraint must be binding. Properties P3 and P4 reflect the strategic decisions that self $t$ makes when it chooses asset allocation levels $\left(x_{t}\right.$ and $\left.z_{t}\right)$. P3 implies that self $t$ will limit self $t+1$ 's liquidity as much as possible $\left(x_{t}=0\right)$ if consumption at time $t+1$ is expected to be high relative to what self $t$ would prefer it to be. P4 implies that self $t$ will not limit self $t+1$ 's liquidity at all $\left(z_{t}=0\right)$ if consumption at time $t+1$ is expected to be low relative to what self $t$ would prefer it to be. Note that the equations associated with P3 and P4 do not contain the $\beta$ term. This omission arises because, from the 
perspective of self $t$, utility trade-offs between period $t+1$ and any period after $t+1$ are independent of the value of $\beta$.

\section{ANALYsis}

In the following subsections I discuss several implications of the golden eggs model. Some of the applications consider the infinite-horizon game that is analogous to the finite-horizon game discussed above. When doing so, I will focus consideration on the equilibrium that is the limit (as the horizon goes to infinity) of the unique finite-horizon equilibrium. ${ }^{10}$

\section{A. Comovement of Consumption and Income}

There is a growing body of evidence that household consumption flows track corresponding household income flows "too" closely, generating violations of the life-cycle/permanent-income consumption model. In particular, household consumption is sensitive to expected movements in household income: e.g., Hall and Mishkin [1982], Zeldes [1989], Carroll and Summers [1991], Flavin [1991], Carroll [1992], Shea [1995], and Souleles [1995]. ${ }^{11}$ Many of these authors find that consumption tracks expected income changes even when consumers have large stocks of accumulated assets.

Several models have been proposed to explain the consump-

10. For the infinite horizon game, a joint strategy, $s$, is resource exhausting if the continuation paths after all histories imply that the intertemporal budget constraint is exactly satisfied:

$$
z_{0}+x_{0}+\sum_{t=1}^{\infty}\left(\prod_{i=1}^{t} R_{i}\right)^{-1} y_{t}=\sum_{t=1}^{\infty}\left(\prod_{i=1}^{t} R_{i}\right)^{-1} c_{t} .
$$

For the infinite-horizon game, I will focus on the equilibrium that satisfies the following infinite-horizon analogs of $\mathrm{P} 1-\mathrm{P} 4$ :

$$
\begin{aligned}
& \text { P1 } u^{\prime}\left(c_{t}\right) \geq \sup _{\tau \geq 1} \beta \delta^{\tau}\left(\prod_{i=1}^{\tau} R_{t+i}\right) u^{\prime}\left(c_{t+\tau}\right) \\
& \text { P2 } u^{\prime}\left(c_{t}\right)>\sup _{\tau \geq 1} \beta \delta^{\tau}\left(\prod_{i=1}^{\tau} R_{t+i}\right) u^{\prime}\left(c_{t+\tau}\right) \Rightarrow c_{t}=y_{t}+R_{t} x_{t-1} \\
& \text { P3 } u^{\prime}\left(c_{t+1}\right)<\sup _{\tau \geq 1} \delta^{\tau}\left(\prod_{i=1}^{\tau} R_{t+i}\right) u^{\prime}\left(c_{t+1+\tau}\right) \Rightarrow x_{t}=0 \\
& \text { P4 } u^{\prime}\left(c_{t+1}\right)>\sup _{\tau \geq 1} \delta^{\tau}\left(\prod_{i=1}^{\tau} R_{t+i}\right) u^{\prime}\left(c_{t+1+\tau}\right) \Rightarrow z_{t}=0 .
\end{aligned}
$$

11. Although Runkle [1989] is unable to reject the permanent income hypothesis, there are reasons to believe his test lacks power (see Shea [1995]). 
tion-income comovement. Carroll [1992] proposes a buffer-stock theory of savings in which impatient consumers with a precautionary savings motive hold little wealth and choose optimal consumption policies in which consumption and income move together over the life-cycle. Gourinchas and Parker [1995] simulate an extended version of this model. Attanasio and Weber [1993] argue that demographic dynamics explain much of the consumption-income comovement.

The golden eggs model provides a new explanation for the observed comovement in consumption and income. In the model, self $t-1$ chooses $x_{t-1}$ to constrain the consumption of self $t$. In this way "early" selves manipulate the cash flow process by keeping most assets in the illiquid instrument. Hence, at any given moment the consumer is effectively liquidity constrained, though the constraint is self-imposed. In equilibrium consumption is exactly equal to the current level of cash flow: $c_{t}=y_{t}+R_{t} x_{t-1}$ (see Lemma 3 in the Appendix for a formal proof). However, this does not imply by itself that consumption will track labor income. Note that $x_{t-1}$ is endogenous, and in equilibrium $x_{t-1}$ covaries negatively with labor income. Self $t-1$ varies $x_{t-1}$ to try to offset the predictable fluctuations in $y_{t}$. When $y_{t}$ is large, self $t-1$ will make $x_{t-1}$ small in an effort to prevent self $t$ from overconsuming.

However, there are limits to the ways in which "early" selves can constrain the choices of "later" selves. Self $t-1$ can only deny self $t$ access to assets that have been accumulated in the past. Self $t-1$ cannot deny self $t$ access to $y_{t}$, labor income at time $t$. So when $y_{t}$ is particularly high (i.e., cash flow at time $t$ is particularly high), consumption at time $t$ will also be high. This implies that on the equilibrium path, predictable movements in income will tend to be reflected in movements in consumption.

An example may help to make this more concrete. Let the horizon be infinite. Assume that labor income follows a trending high-low process: $y_{t}=\bar{y} e^{g t}$ when $t$ is odd, $y_{t}=y e^{g t}$ when $t$ is even. Assume that the interest rate is constant and $\exp (\rho g)=\delta R$. (This last relationship is motivated by the steady state results below.) Assume that $\left\{y_{t}\right\}_{t=1}^{\infty}$ satisfies A1. Finally, assume that $x_{0}=0, z_{0} \geq$ 0 , and $z_{0}$ not be "too" large relative to the labor income variability. Specifically, $z_{0}$ must satisfy the relationship,

$$
u^{\prime}(\bar{y}) \leq \delta R u^{\prime}\left(\underline{y} e^{g}+z_{0}\left(1-e^{2 g} / R^{2}\right) e^{g}\right) .
$$

Then the equilibrium consumption path is 


$$
c_{t}= \begin{cases}y_{t} & \text { if } t \text { odd } \\ y_{t}+z_{0}\left(1-e^{2 g} / R^{2}\right) e^{g t} & \text { if } t \text { even } .\end{cases}
$$

Figure II graphs the labor income path and equilibrium consumption path, using parameter values, $\beta=0.6, R=1.04, g=$ $0.02, \bar{y}=z_{0} / 3=1$, and $\bar{y}=0.8 .{ }^{12}$ Two properties stand out. First, the illiquid asset is exclusively used to augment consumption in the even periods, i.e., in the periods with relatively low labor income. However, this increase is not sufficient to smooth consumption. A regression of $\Delta \ln c_{t}$ on $\Delta \ln y_{t}$ yields a coefficient of .40 . Since the income process is completely deterministic, this implies that predictable changes in income are associated with changes in consumption. Hence, consumption tracks income despite the fact that the consumer in this example controls a substantial asset stock $(K / Y \approx 3)$.

\section{B. Aggregate Saving}

In most intertemporal rational choice models, high discount rates are a necessary condition for consumption-income comovement. Such relatively high discount rates, however, tend to imply relatively low levels of capital accumulation in general equilibrium (see Aiyagari [1992]). The golden eggs model generates consumption-income comovement even when actors are wealthy. This is because in equilibrium decisions to dissave out of the illiquid asset stock do not depend on $\beta$. Self $t$ is not able to consume the illiquid asset immediately, so self $t$ does not consider tradeoffs between consumption today and consumption tomorrow when dissaving from the illiquid instrument. Instead self $t$ considers trade-offs between consumption at $t+1$ and consumption at periods after $t+1$. The value of $\beta$ is superfluous for such a decision-from self $t$ 's perspective-and hence the steady state capital stock is independent of $\beta$.

The following general equilibrium analysis formalizes this intuition. Assume that there exists a continuum of individual agents indexed by the unit interval. Individual decision and state variables are represented with an $i$ index (e.g., $c_{t}(i)$ ). Consider a standard Cobb-Douglas production function with aggregate capital $K_{t}$, aggregate labor $L_{t}$, and exogenous productivity $A_{t}$ :

12. The remaining variables, $\delta$ and $\rho$, may take on any values that satisfy the steady state condition: $\exp (\rho g)=\delta R$. 


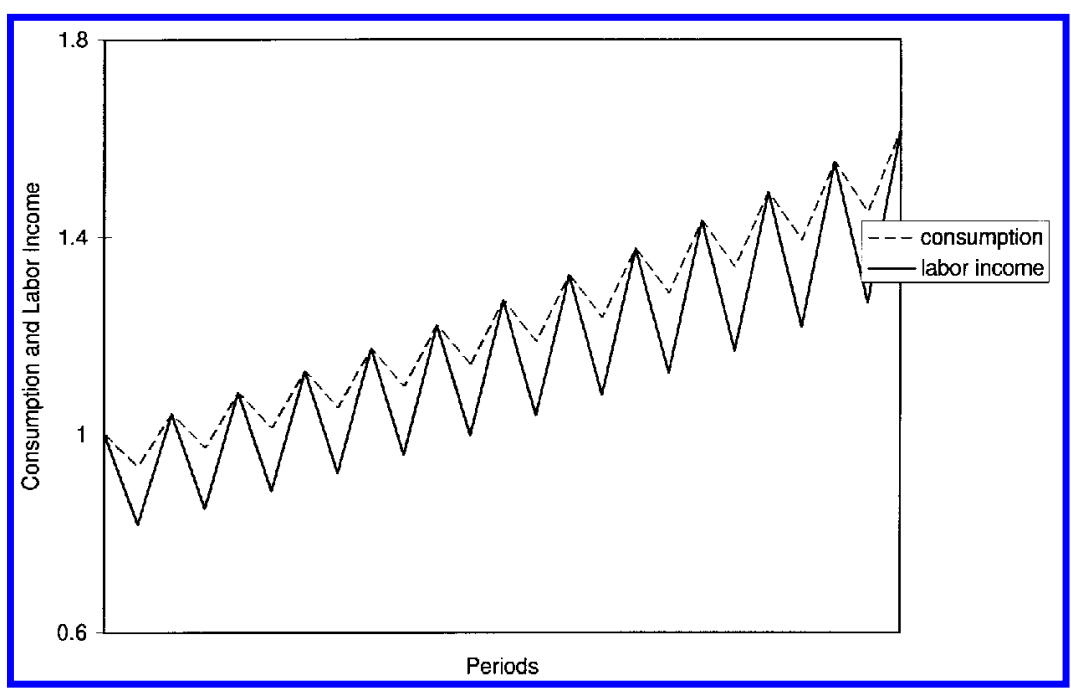

Figure II

Consumption and Labor Income

$$
Y_{t}=A_{t} K_{t}^{\alpha} L_{t}^{1-\alpha} .
$$

Aggregate capital is composed of the liquid and illiquid capital holdings of individual agents in the economy:

$$
K_{t} \equiv \int_{0}^{1}\left[x_{t-1}(i)+z_{t-1}(i)\right] d i .
$$

Recall that labor is assumed to be supplied inelastically, so $L(i)=$ 1 , and

$$
L_{t} \equiv \int_{0}^{1} L_{t}(i) d i=1 .
$$

In competitive equilibrium labor receives its marginal product, so labor income of agent $i$ at time period $t$ is given by $y_{t}(i)=$ $(1-\alpha) Y_{t}$. Competitive equilibrium also implies that capital receive its marginal product, so $R_{t}=1+\alpha Y_{t} / K_{t}-d$, where $d$ is the rate of depreciation. Liquid and illiquid gross asset returns of agent $i$ at time period $t$ are, respectively, $R_{t} x_{t-1}$ and $R_{t} z_{t-1}$. Finally, $A_{t}$ is assumed to grow exogenously at rate $g_{A}$, so in steady state, capital and output must grow at rate $g_{A} /(1-\alpha) \equiv g$.

Proposition 1. In the economy described above there exists a unique steady state that satisfies A1. In that steady state

$$
\exp (\rho g)=R \delta \text {. }
$$


The important property of the steady state identified in Proposition 1 is that the parameter $\beta$ does not appear in the equation relating the discount rate and the growth rate. So $\beta$ can be calibrated to generate excess sensitivity (i.e., consumptionincome comovement), while $\delta$ can be calibrated to match the historical capital-output ratio of three. If $\beta$ is in the interior of the unit interval, then the equilibrium path will exhibit consumption-income tracking (e.g., see the example in previous subsection). Meanwhile, $\delta$ can be chosen to satisfy the equation,

$$
\rho g \approx r-(1-\delta)=\alpha(Y / K)-d-(1-\delta),
$$

which is a log-linearized version of equation (2). Setting $\delta=0.98$ rationalizes $K / Y=3$, assuming that the other parameters in the equation take standard values: $\rho=1, g=0.02, \alpha=0.36, d=$ 0.08 .

\section{Asset-Specific MPCs}

Thaler [1990] argues that consumers have different marginal propensities to consume for different categories of assets. For example, he presents evidence that an unexpected increase in the value of an equity portfolio will have a very small effect on consumption, while an unexpected job-related bonus will be immediately consumed. Thaler divides consumer wealth into three categories: current income, net assets, and future income. He cites a wide body of evidence which suggests that "the MPC from [current income] is close to unity, the MPC from [future income] is close to zero, and the MPC from [net assets] is somewhere in between." Thaler explains this behavior by postulating that consumers use a system of nonfungible mental accounts to guide rule-of-thumb decision-making. By contrast, the golden eggs model predicts that even fully rational consumers will exhibit asset-specific MPCs. ${ }^{13}$

In the golden eggs model the current self is always endogenously liquidity constrained on the equilibrium path. So the MPC out of current cash flow is one. Proposition 2 formalizes this claim.

13. Laibson [1994b] proposes another hyperbolic discounting model that generates some mental accounting behavior. In Laibson [1994b] rational consumers set up a system of self-rewards and self-punishments to motivate later selves to exert high effort. Laibson [1994b] discusses effort-related mental accounts, while the current paper discusses liquidity-related mental accounts. 
Proposition 2. Fix a consumption game in which inequality $\mathrm{A} 1$ is strictly satisfied. Let $c_{t}=c_{t}\left(R_{t} x_{t-1}, R_{t} z_{t-1}\right)$ represent the equilibrium (Markov) consumption strategy of self $t$. Then,

$$
\frac{\partial c_{t}}{\partial\left(R_{t} x_{t-1}\right)}=1 \quad \forall t \geq 2,
$$

when the partial derivative is evaluated on the equilibrium path.

In this subsection I contrast this MPC with its analog for illiquid assets. At first glance it is not clear how to best make this comparison. I will consider two approaches.

Proposition 3. Fix a consumption game in which inequality A1 is strictly satisfied. Let $c_{t}\left(R_{t} x_{t-1}, R_{t} z_{t-1}\right)$ represent the equilibrium (Markov) consumption strategy of self $t$. Then,

$$
\frac{\partial c_{t}}{\partial\left(R_{t} z_{t-1}\right)}=0 \quad \forall t \geq 2,
$$

when the partial derivative is evaluated on the equilibrium path.

This result is not surprising, since on the equilibrium path the individual always faces a self-imposed liquidity constraint. Small perturbations to the illiquid asset stock are not sufficient to stop the current self's liquidity constraint from being binding. A more interesting question to ask is how a perturbation to $z_{t-1}$ affects the choice of $x_{t}$. Recall that liquid assets set aside at time $t$ will be completely consumed at time $t+1$. Unfortunately, the value of $\partial x_{t} / \partial\left(R_{t} z_{t-1}\right)$ can take on any value between zero and one. For example, the partial derivative is equal to zero if the equilibrium value of $x_{t}$ is equal to zero. The partial derivative is equal to unity if $t$ is the penultimate period of the game. It would be helpful to develop an MPC measure that provides a representative value of $\partial x_{t} / \partial\left(R_{t} z_{t-1}\right)$. The following proposition introduces such a measure, by considering the geometric average of MPCs over a deterministic business cycle of duration $\tau$.

Proposition 4. Fix any $\infty-$ horizon consumption game with $R_{t}=$ $R \forall t$. Fix a particular value of $\tau \geq 1$. Assume that $\left\{y_{t}\right\}_{t=1}^{\infty}$ satisfies A1, and $y_{t+\tau}=\exp (\tau g) y_{t}, \forall t \geq 0$. Assume that $\exp (\rho g)=\delta R$. Let $x_{t}=x_{t}\left(R \cdot x_{t-1}, R \cdot z_{t-1}\right)$ represent the equilibrium (Markov) consumption strategy of self $t$. Let 


$$
1-M P C_{t}^{z} \equiv\left[\prod_{i=0}^{\tau-1}\left(1-\frac{\partial x_{t+i}}{\partial\left(R z_{t+i-1}\right)}\right)\right]^{1 / \tau}
$$

evaluated on the equilibrium path. Then,

$$
M P C_{t}^{z}=M P C^{z} \equiv 1-\left(\delta R^{1-\rho}\right)^{1 / \rho} \quad \forall t \geq 2 .
$$

Note that Proposition 4 assumes that the growth rate of labor income is related to the return on capital by the steady state equation in Proposition 2: $\exp (\rho g)=\delta R$. Note also that the resulting measure of the marginal propensity to consume, 1 $\left(\delta R^{1-\rho}\right)^{1 / \rho}$, is equivalent to the marginal propensity to consume in the standard Ramsey model with no liquidity constraints and exponential discount function $\delta^{t}$. For all reasonable parameter values $M P C^{z}$ is close to zero. Recall that the first proposed measure of the MPC out of illiquid assets (i.e., the MPC measure introduced in Proposition 3) was exactly equal to zero. Finally, contrast these proposed measures of the MPC out of illiquid assets (which take values close to or exactly equal to zero) with the unity marginal propensity to consume out of liquid assets.

\section{Ricardian Equivalence}

In the economy analyzed in this paper, the sequence of exogenous cash flows matters, in a way that is independent of the present value of those cash flows. This is immediately apparent from Figure II. Because taxation schemes affect these exogenous cash flows, Ricardian equivalence will be violated. Moreover, the model generates such violations even when the consumer has a large asset stock at all times. Hence, Ricardian equivalence is violated for all agents, whether or not they hold substantial wealth.

\section{E. Declining Savings Rates in the 1980s}

The golden eggs model may help to explain the decline in U. S. savings rates during the 1980s. I pursue two approaches in this subsection. The first explanation is driven by the fact that during the 1980s a relatively large proportion of national income was realized as cash flow to consumers. However, I am unsatisfied with this first story for reasons that I describe below. Hence, I focus most of my attention on a second explanation that is driven by developments in the consumer credit market.

Hatsopoulos, Krugman, and Poterba [1989] document the ob- 
servation that cash flow to consumers (as a percentage of NNP) was high during the 1980s relative to the 1970s. They report that from 1970-1979 cash flow averaged 77.9 percent of NNP, while the corresponding number for the $1980-1987$ period was 80.8 percent. They trace this increase to several sources, notably higher interest income (4.5 percentage points), higher transfers (2.2 percentage points), and higher after-tax cash from takeovers (0.6 percentage points). ${ }^{14}$

Using aggregate data, Hatsopoulos, Krugman, and Poterba [1989] estimate a high marginal propensity to consume out of current cash flow. Coupling this result with the higher cash flow levels, they are able to explain most of the savings decline in the 1980 s. However, they do not explain why consumers should have such a high propensity to consume out of cash flow. The golden eggs model complements their analysis by providing a model that explains the high MPC. However, note that the golden eggs model can only explain the high MPC out of cash flow; the model cannot explain why the cash flow was high in the first place. Hence, application of the golden eggs model may only relabel the puzzle, changing it from a consumption puzzle to a cash flow puzzle.

The golden eggs model suggests a second explanation for the low level of savings during the past decade. The 1980 s was a period of rapid expansion in the U. S. consumer credit market. Increasing access to instantaneous credit has reduced the effectiveness of commitment devices like illiquid assets. The golden eggs model predicts that the elimination of commitment devices would lower the level of capital accumulation. I will show that if the credit market were to become sufficiently sophisticated that consumers could instantaneously borrow against their illiquid assets, then the steady state capital-output ratio would fall. I calibrate this fall at the end of the subsection.

The rapid expansion of the U. S. consumer credit market provides the starting point for the argument summarized in the previous paragraph. One example of the expansion in instantaneous credit has been the growth in credit cards. ${ }^{15}$ In 1970 only 16 percent of all U. S. families had a third party credit card (e.g., prede-

14. Offsetting falls in cash flow occurred in labor income $(-0.3$ percentage points), noninterest capital income in disposable income (-2.0 percentage points), and taxes $(-2.1$ percentage points).

15. Another important development in the U. S. credit market has been the expanded use of home equity lines of credit. Before the mid-1980s home equity lines of credit were almost unheard of. By 1993-1994 8.3 percent of homeowners had a home equity line of credit. See Canner and Luckett [1994], p. 572. 
cessors of current cards like Visa and MasterCard). By 198954 percent had one. ${ }^{16}$ During this same period credit card acceptance by retailers also increased dramatically. Large retailers did not accept credit cards during the 1970s. In 1979 J. C. Penney broke ranks with its competitors and became the first major retailer to accept third party credit cards. By the end of the 1980s almost all large retailers accepted third party cards. The growth of ATMs (automatic teller machines) augmented the impact of the credit card expansion by enabling credit cardholders to readily receive cash advances. Regional and national ATM networks first began to form in the late 1970 s and early $1980 \mathrm{~s} .{ }^{17}$ Altogether these developments led to an explosion in revolving credit, which is principally composed of credit card debt. From 1970 to 1995, revolving credit grew from 3.7 percent to 36.3 percent of total consumer credit. ${ }^{18}$ No single year stands out as the date at which most consumers experienced a sharp increase in their personal access to instantaneous credit. However, it is safe to say that by the mid-1980s most families had a third party credit card, and this card could be used in most large retail stores, or could be used in ATMs to receive cash advances to make purchases in the stores that still did not accept credit cards. Together these observations suggest that the mid-1980s represents the first time that a representative U. S. family had instantaneous access to consumer credit, or could rapidly apply for such access.

Introducing instantaneous credit into the golden eggs model dramatically changes the equilibrium analysis. (Recall that the original model had credit which could be accessed with a oneperiod delay.) In the original model consumption was bounded above by cash on hand:

$$
c_{t} \leq y_{t}+R_{t} x_{t-1} \text {. }
$$

With instantaneous access to credit, consumption is now constrained to lie below the sum of cash on hand and the value of all credit lines that can be instantaneously set up or are already set

16. See Canner and Luckett [1992], p. 656.

17. See Mandell [1990] for a short history of the credit card industry.

18. Consumer credit includes automobile loans, revolving credit, "other" installment credit, and noninstallment credit. "Other" installment credit includes "mobile home loans and all other installment loans not included in automobile or revolving credit, such as loans for education, boats, trailers, or vacations. These loans may be secured or unsecured. Noninstallment credit is credit scheduled to be repaid in a lump sum, including single-payment loans, charge accounts, and service credit" [Economic Report of the President 1996, Table B-73]. 
up. I assume that the value of these existing and potential credit lines is approximately equal to the value of the illiquid assets held by the consumer. Hence, consumption is now constrained by

$$
c_{t} \leq y_{t}+R_{t} x_{t-1}+R_{t} z_{t-1} .
$$

In all other ways the model remains the same.

Proposition 5. Consider the general equilibrium economy analyzed above, but now assume that consumers can instantaneously borrow against their illiquid asset. This economy is equivalent to one in which there is no illiquid asset (i.e., $x$ is the only asset). In such an economy there exists a unique steady state, and in that steady state,

$$
\exp (\rho g)=\beta \delta R+(1-\beta) \delta \exp (g) .
$$

CoRollary. In the steady state characterized in Proposition 5 the capital-output ratio is less than the steady state capitaloutput ratio in the economy with the commitment technology.

Table I reports the magnitude of the reduction in steady state capital that occurs when financial innovation moves an economy from a golden eggs financial technology to a new financial technology in which it is possible to instantaneously borrow against the illiquid asset (i.e., when financial innovation eliminates the illiquidity that makes partial commitment possible). The entries of Table I are derived in five steps. First, I assume that the U. S. economy has historically been a golden eggs economy, with $\alpha=$ $0.36, d=0.08, g=0.02$, and $K / Y=3$. Second, I calibrate preference parameters $\rho$ and $\delta$ based on equation (2) (the steady state equation in golden eggs economies) and the competitive equilibrium condition, $r=\alpha Y / K-d=(0.36) \frac{1}{3}-0.08$. (Recall that equation (2) is independent of $\beta$.) These equations jointly imply that

$$
\exp (\rho(0.02))=\delta(1.04) .
$$

Third, I take the set of preference parameter values derived in step 2 (i.e., defined in equation (5)) and plug that set into equation (4), the new steady state equation (i.e., the steady state equation associated with the economy in which consumers can instantaneously borrow against their illiquid assets). This yields the following "constrained" steady state equation that holds in the new economy: 
TABLE I

Steady State Interest Rates and Capital-Output Ratios in Economies With AND Without Partial COMmitment

\begin{tabular}{llllr}
\hline \hline & \multicolumn{2}{c}{$\begin{array}{c}\text { With commitment } \\
\text { (i.e., no instantaneous } \\
\text { credit) }\end{array}$} & \multicolumn{2}{c}{$\begin{array}{c}\text { Without commitment } \\
\text { (i.e., instantaneous } \\
\text { credit) }\end{array}$} \\
\hline & $r$ & $\frac{K}{Y}$ & $r$ & $\frac{K}{Y}$ \\
\hline$\beta=0.2$ & 0.040 & 3.00 & 0.119 & 1.81 \\
$\beta=0.4$ & 0.040 & 3.00 & 0.070 & 2.40 \\
$\beta=0.6$ & 0.040 & 3.00 & 0.053 & 2.70 \\
$\beta=0.8$ & 0.040 & 3.00 & 0.045 & 2.88 \\
$\beta=1.0$ & 0.040 & 3.00 & 0.040 & 3.00 \\
\hline \hline
\end{tabular}

$$
1.04=\beta R+(1-\beta) \exp (.02) .
$$

Note that this constrained steady state relationship is independent of $\rho$ and $\delta$, and depends exclusively on $\beta$ and $R$. Fourth, I vary $\beta$, the only free preference parameter in the constrained new steady state equation, and calculate the corresponding capitaloutput ratios (again using the competitive equilibrium relationship $r=\alpha(Y / K)-d)$. Fifth, I compare these new capital-output ratios with the historical capital-output ratio.

Note that when commitment is available, the steady state interest rate and capital-output ratio are independent of the value of $\beta$ (see Proposition 1). Now consider an example of a transition from a commitment economy to an economy without commitment. For a $\beta$ value of 0.6 , elimination of the commitment technology raises the steady state real interest rate 1.3 percentage points. This corresponds to a reduction in the capital-output ratio of 0.3 .

These results should be compared with actual U. S. experience during the 1980s and 1990s. The model predicts that capital accumulation should have fallen at the same time that consumers gained access to instantaneous credit (approximately the mid1980s). All measures of capital accumulation show a marked downturn that starts in the 1980s and continues into the 1990s. For example, U. S. personal savings as a percent of disposable personal income fell from an average of 7.3 percent from 19461984 , to an average of 5.3 percent from 1985-1994. The 19851994 period had the lowest average saving rate of any ten-year 
span in the postwar period. ${ }^{19}$ The ratio of national net worth to gross national product (i.e., the U. S. capital-output ratio) fell from an average of 3.2 from 1946-1984, to 2.8 in 1994. The 1994 value is the low point for the series in the postwar period. ${ }^{20}$

\section{F. Welfare Analysis of Financial Innovation}

The introduction of instantaneous credit increases consumers' choice sets. Standard economic models imply that this development might lower levels of capital accumulation, but would raise consumer welfare. Yet, in the United States, policy-makers and pundits are concerned that instantaneous credit is somehow bad for consumers.

The golden eggs framework provides a formal model of the costs of financial innovation. By enabling the consumer to instantaneously borrow against illiquid assets, financial innovation eliminates the possibility for partial commitment. This has two effects on the welfare of the current self. First, the current self no longer faces a self-imposed liquidity constraint and can therefore consume more in its period of control. Second, future selves are also no longer liquidity constrained and may also consume at a higher rate out of the wealth stock that they inherit. The first effect makes the current self better off. The second effect makes the current self worse off (since the current self would like to constrain the consumption of future selves). Under most parameterizations the impact of the second effect dominates, and the welfare of the current self is reduced.

Formally, I measure the welfare loss by calculating the minimum one-time payment-paid to a representative consumerwhich would induce the representative consumer to switch from an infinite horizon golden eggs economy to an infinite horizon instantaneous credit economy. (Using the notation of Section II, the hypothetical payment that induces indifference is made during subperiod 2 of time $t$, and the indifference is from the perspective of self $t$.) I assume that the representative consumer starts in

19. National Income and Product Accounts, Table 2.1, Bureau of Economic Analysis, U. S. Department of Commerce.

20. National net worth is calculated from Tables B.11 and B.109 in Balance Sheets for the U. S. Economy 1945-94, Board of Governors of the Federal Reserve System. National net worth represents the sum of lines 1 and 30 from Table B.11 added to the difference between lines 43 and 42 from Table B.109. Gross national product is calculated by the Bureau of Economic Analysis, U. S. Department of Commerce. 
the steady state of the golden eggs economy; this steady state is characterized in Proposition 1. The representative agent remains in that steady state if she remains in the golden eggs economy. By contrast, if the representative agent switches to the instantaneous credit economy (i.e., if she switches to the economy in which it is possible to instantaneously borrow against illiquid assets), then the new economy asymptotically converges to the steady state characterized in Proposition 5. The starting point for this convergence is the golden eggs steady state capital stock augmented (depleted) by a payment at time period one.

I calibrate this exercise with $\alpha=0.36, d=0.08, g=0.02$, $\delta=0.98$ and $\rho=1$, and I assume that the golden eggs steady state is characterized by the historical capital-output ratio $K / Y=$ 3 . Note that these values are consistent with the steady state equation for the golden eggs economy (see Proposition 1).

The convergence path for the economy in which instantaneous borrowing is possible is characterized by a nonstandard Euler equation derived in Laibson [1996]:

$$
u^{\prime}\left(c_{t}\right)=R_{t+1} \delta u^{\prime}\left(c_{t+1}\right)[\lambda(\beta-1)+1],
$$

where $\lambda$ is given $b y^{21}$

$$
\lambda=\frac{1-\delta}{1-\delta(1-\beta)} .
$$

Note that when $\beta=1$ this Euler equation reduces to the standard case. To solve for the convergence path conditional on a starting level of financial wealth, it is necessary to search for the unique sequence $\left\{c_{t}, R_{t}\right\}_{t=1}^{\infty}$ that is 1 ) consistent with the nonstandard Euler equation given above; 2 ) consistent with the dynamic budget constraint; 3) consistent with the capital market competitive equilibrium condition; and 4) consistent with asymptotic convergence to the steady state characterized in Proposition 5. Identifying this sequence can be reduced to a one-dimensional search over values of $c_{1}$ : start with a guess of the equilibrium value of $c_{1}$; combine this value of $c_{1}$ with the dynamic budget constraint and the competitive equilibrium conditions to generate $R_{2}$; use the nonstandard Euler equation to calculate $c_{2}$ as a function of $c_{1}$ and $R_{2}$; iterate the last two steps to generate a sequence $\left\{c_{t}, R_{t}\right\}_{t=1}^{\infty}$ that can be checked for asymptotic steady state convergence; if the sequence does not converge, start with a new guess for $c_{1}$.

This algorithm provides a way of calculating the convergence

21. The derivation for $\lambda$ uses the calibration assumption $\rho=1$. 
TABLE II

Payments to Induce Indifference BETWEEN GOLDEN EGGS ECONOMY AND INSTANTANEOUS CREDIT ECONOMY

\begin{tabular}{lc}
\hline \hline & $\begin{array}{c}\text { Payment as } \\
\text { percent of output }\end{array}$ \\
\hline$\beta=0.2$ & 69.6 \\
$\beta=0.4$ & 29.5 \\
$\beta=0.6$ & 9.0 \\
$\beta=0.8$ & 1.6 \\
$\beta=1.0$ & 0.0 \\
\hline \hline
\end{tabular}

path given any level of initial financial wealth in the instantaneous credit economy. Once this has been done, it is straightforward to calculate the level of initial financial wealth in the instantaneous credit economy that induces indifference with the level of initial financial wealth in the golden eggs economy. The payment level is the difference between these two financial wealth levels. The payment level is reported in Table II, where it is normalized by the level of output at time of payment. ${ }^{22}$ Note that a positive payment implies that the consumer needs compensation to induce her to willingly switch to the instantaneous credit scenario. Hence, if payment were withheld, the consumer would be worse off in the instantaneous credit scenario. Table II reports these normalized payments for a range of $\beta$ values.

Note that when $\beta=1$ there is no welfare loss. When $\beta=1$, the consumer's preferences are not dynamically inconsistent, and the consumer has no need to constrain her future selves. By contrast, for the other cases, $(\beta \in\{0.2,0.4,0.6,0.8\})$ the consumer is made worse off by financial innovation. Being able to borrow against illiquid assets is welfare reducing. However, note that this is not always the case. For $\beta$ values sufficiently close to zero, the consumer is made better off by being able to splurge almost all of her financial wealth immediately. However, for the range of reasonable $\beta$ values reported in Table II, the consumer is always made worse off by financial innovation.

Of course the costs of financial innovation explored above may be offset by unmodeled gains, like being able to consume in unforeseen emergencies (which are ruled out in the deterministic framework of this paper). The point of this subsection is to dem-

22. Note that output at time of payment is the same under the two scenarios, since output at any given period is determined by capital put aside in the previous period. 
onstrate that there are potentially important costs that accompany those other well-known benefits of extra liquidity.

\section{Evaluation and Extensions}

I have analyzed the consumption problem of a dynamically inconsistent decision-maker who has access to a crude commitment mechanism. The model helps to explain many of the empirical puzzles in the consumption literature, notably consumptionincome tracking and asset-specific MPCs. However, the model has several drawbacks that suggest four important areas to pursue extensions.

First, the golden eggs model does not explain how consumers accumulate assets in the first place. Note that consumption is always greater than labor income on the equilibrium path. However, this is less of a problem than it might first appear. Although there is evidence that individuals often consume less than they earn in labor income, most of this saving is nondiscretionary (e.g., pension contributions, life-insurance payments, mortgage payments, and other payments to creditors). Bringing such "nondiscretionary savings" into the model can be done very simply. For example, the consumer could elect to take on a 30-period mortgage obligation at time zero, represented by a mortgage payment of $m$ for the next 30 periods. Then the consumer's cash flow at time $t \leq 30$ would be $y_{t}+R_{t} x_{t-1}-m$, which would be less than $y_{t}$ if $m$ were greater than $R_{t} x_{t-1}$. A related way to model nondiscretionary savings would be to let the consumer set $x_{t-1}$ itself less than zero, (e.g., $\underline{x} \leq x_{t-1}$, where $\underline{x}<0$ ).

A second problem associated with the model is the anomalous prediction that consumers will always face a binding selfimposed liquidity constraint. For example, the golden eggs model predicts that after making their consumption choice, consumers should have no liquid funds left in their bank accounts. This prediction contradicts many consumers' experiences. However, this problem can be readily addressed by introducing a precautionary savings motive for holding liquidity. For example, consider a continuous-time analog of the golden eggs model, and assume that instantaneous liquidity needs arrive with some hazard rate. Then in equilibrium the consumer will only rarely completely exhaust her liquidity.

A third problem with the golden eggs model is that some con- 
sumers may not need to use external commitment devices (like illiquid assets) to achieve self-control. Consumers may have internal self-control mechanisms, like "will power" and "personal rules." In Laibson [1994a] I analyze an infinite-horizon consumption/savings game with no external commitment technology and find a multiplicity of Pareto-rankable equilibria. I interpret this multiplicity as a potential model for self-control and willpower. However, this approach raises problematic and as yet unresolved equilibrium selection problems. More work is needed to develop theoretically robust models of internal self-control mechanisms, and to empirically validate such models.

The fourth problem with the golden eggs model is that some consumers may have access to an array of "social" commitment devices that are far richer than the simple illiquid asset proposed in this essay. In Laibson [1994b] I analyze the problem of a consumer who can use social systems like marriage, work, and friendship to achieve personal commitment. Future work should try to identify the most important mechanisms that consumers use to overcome the self-control problems induced by hyperbolic preferences.

\section{APPENDIX}

Theorem 1 is proved with four intermediate lemmas. These lemmas apply to the game described in Theorem 1.

Lemma 1. Let $s$ be a resource-exhausting element of the joint strategy space $S$. Assume that $s$ satisfies $\mathrm{P} 1-\mathrm{P} 4$. Then for all histories $h_{t}$, strategy $s$ implies that $c_{t} \geq y_{t}$.

Proof of Lemma 1. Use induction to prove result. Fix a period $t$ and feasible history, $h_{t}$. Let $s \mid h_{t}=\left\{c_{t+\tau}^{A}, x_{t+\tau}^{A}, z_{t+\tau}^{A}\right\}_{\tau=0}^{T-t}$. Assume that $c_{t+\tau} \geq y_{t+\tau} \forall \tau \geq 1$. By P1, $u^{\prime}\left(c_{t}\right) \geq \max _{\tau} \epsilon_{\{1, \ldots, T-t} \beta \delta^{\tau}$ $\left(\prod_{i=1}^{\tau} R_{t+i}\right) u^{\prime}\left(c_{t+\tau}\right)$. If this inequality is strict, then P2 implies that $c_{t} \geq y_{t}$. So WLOG assume that $u^{\prime}\left(c_{t}\right)=\max _{\tau \geq 1} \beta \delta^{\tau}\left(\Pi_{i=1}^{\tau} R_{t+i}\right) u^{\prime}\left(c_{t+\tau}\right)$ :

$$
\begin{aligned}
u^{\prime}\left(c_{t}\right) & =\max _{\tau \in\{1, \ldots, T-t-1\}} \beta \delta^{\tau}\left(\prod_{i=1}^{\tau} R_{t+i}\right) u^{\prime}\left(c_{t+\tau}\right) & & \text { by assumption } \\
& \leq \max _{\tau \in\{1, \ldots, T-t-1\}} \beta \delta^{\tau}\left(\prod_{i=1}^{\tau} R_{t+i}\right) u^{\prime}\left(y_{t+\tau}\right) & & \text { by assumption } \\
& \leq u^{\prime}\left(y_{t}\right) & & \text { by A1. }
\end{aligned}
$$


So $u^{\prime}\left(c_{t}\right) \leq u^{\prime}\left(y_{t}\right)$, and hence $c_{t} \geq y_{t}$. After confirming that $c_{T} \geq y_{T}$ (by resource exhaustion), the proof is completed by applying a standard induction argument.

Lemma 2. Let $s^{A}$ and $s^{B}$ be resource-exhausting elements of the joint strategy space $S$. Assume that $s^{A}$ and $s^{B}$ satisfy P1-P4. Let $\left\{c_{t}^{A}, x_{t}^{A}, z_{t}^{A}\right\}_{t=1}^{T}$ and $\left\{c_{t}^{B}, x_{t}^{B}, z_{t}^{B}\right\}_{t=1}^{T}$ be the respective paths of actions generated by $s^{A}$ and $s^{B}$. Fix a particular value of $t$, and assume $c_{t+\tau}^{A} \geq \mathrm{c}_{t+\tau}^{B} \forall \tau \geq 1$, with $c_{t+\tau}^{A}>c_{t+\tau}^{B}$ for at least one $\tau \geq 1$. Then $c_{t}^{A} \geq c_{t}^{B}$.

Proof of Lemma 2. By P1, $u^{\prime}\left(c_{t}^{A}\right) \geq \max _{\tau \in\{1, \ldots, T-1\}} \beta \delta^{\tau}$ $\left(\Pi_{i=1}^{\tau} R_{t+i}\right) u^{\prime}\left(c_{t+\tau}^{A}\right)$. If this is satisfied with equality, then

$$
\begin{aligned}
u^{\prime}\left(c_{t}^{B}\right) & \geq \max _{\tau \in\{1, \ldots, T-t-1\}} \beta \delta^{\tau}\left(\prod_{i=1}^{\tau} R_{t+i}\right) u^{\prime}\left(c_{t+\tau}^{B}\right) & & \text { by P1 } \\
& \geq \max _{\tau \in\{1, \ldots, T-t-1\}} \beta \delta^{\tau}\left(\prod_{i=1}^{\tau} R_{t+i}\right) u^{\prime}\left(c_{t+\tau}^{A}\right) & & \text { by assumption } \\
& =u^{\prime}\left(c_{t}^{A}\right) & & \text { by assumption. }
\end{aligned}
$$

Hence, $u^{\prime}\left(c_{t}^{B}\right) \geq u^{\prime}\left(c_{t}^{A}\right)$, implying that $c_{t}^{A} \geq c_{t}^{B}$. So WLOG assume that $u^{\prime}\left(c_{t}^{A}\right)>\max _{\tau \in\{1, \ldots, T-t-1\}} \beta \delta^{\tau}\left(\prod_{i=1}^{\tau} R_{t+i}\right) u^{\prime}\left(c_{t+\tau}^{A}\right)$. By P2, $c_{t}^{A}=y_{t}$ $+R_{t} x_{t-1}$. If $t=1$, then $c_{t}^{A} \geq c_{t}^{B}$, since $c_{1}^{B} \leq y_{1}+R_{1} x_{0}=c_{1}^{A}$. So WLOG assume that $t \geq 2$. If $x_{t-1}^{B} \geq x_{t-1}^{A}$, then $c_{t}^{B} \leq y_{t}+R_{t} x_{t-1}^{B} \leq$ $y_{t}+R_{t} x_{t-1}^{A}=c_{t}^{A}$. So WLOG assume $x_{t-1}^{B}>x_{t-1}^{A} \geq 0$.

$$
\begin{aligned}
0 & <\sum_{\tau=1}^{T-t}\left(\prod_{i=1}^{\tau} R_{t+i}^{-1}\right)\left(c_{t+\tau}^{A}-c_{t+\tau}^{B}\right) & & \text { by assumption } \\
& \leq \sum_{\tau=1}^{T-t}\left(\prod_{i=1}^{\tau} R_{t+i}^{-1}\right)\left(c_{t+\tau}^{A}-y_{t+\tau}\right) & & \text { by Lemma } 1 \\
& =R_{t}\left(x_{t-1}^{A}+z_{t-1}^{A}\right)-c_{t}^{A}+y_{t}^{A} & & \text { by res. exhaust. } \\
& =R_{t} z_{t-1}^{A} & & \text { as } c_{t}^{A}=y_{t}+R_{t} x_{t-1}^{A} .
\end{aligned}
$$

So $z_{t-1}^{A}>0$, and,

$$
\begin{aligned}
u^{\prime}\left(c_{t}^{B}\right) & \geq \max _{\tau \in\{1, \ldots, T-t-1\}} \delta^{\tau}\left(\prod_{i=1}^{\tau} R_{t+i}\right) u^{\prime}\left(c_{t+\tau}^{B}\right) & & \text { by P3 and } x_{t-1}^{B}>0 \\
& \geq \max _{\tau \in\{1, \ldots, T-t-1\}} \delta^{\tau}\left(\prod_{i=1}^{\tau} R_{t+i}\right) u^{\prime}\left(c_{t+\tau}^{A}\right) & & \text { by assumption } \\
& \geq u^{\prime}\left(c_{t}^{A}\right) & & \text { by P4 and } z_{t-1}^{A}>0 .
\end{aligned}
$$

Hence, $u^{\prime}\left(c_{t}^{B}\right) \geq u^{\prime}\left(\mathrm{c}_{t}^{A}\right)$, implying that $c_{t}^{A} \geq c_{t}^{B}$. 
Lemma 3. Let $s$ be a resource-exhausting element of the joint strategy space $S$. Assume that $s$ satisfies P1-P4. Let $\left\{c_{t}, x_{t}\right.$, $\left.z_{t}\right\}_{t=1}^{T}$ represent the path of actions generated by $s$. Then $c_{t}=$ $y_{t}+R_{t} x_{t-1} \forall t \geq 2$.

Proof of Lemma 3. Suppose that $c_{t}<y_{t}+R_{t} x_{t-1}$ for some $t \geq 2$ and look for a contradiction. By P1 and P2, $u^{\prime}\left(c_{t}\right)=$ $\max _{\tau \in\{1, \ldots,} T_{T-t-1\}} \quad \beta \delta^{\tau}\left(\Pi_{i=1}^{\tau} R_{t+i}\right) u^{\prime}\left(c_{t+\tau}\right), \quad$ so $\quad u^{\prime}\left(c_{t}\right)<$ $\max _{\tau \in\{1, \ldots, T-t-1\}} \delta^{\tau}\left(\prod_{i=1}^{\tau} R_{t+i}\right) u^{\prime}\left(c_{t+\tau}\right)$. Hence, by P3, $x_{t-1}=0$. So $c_{t}<$ $y_{t}$, which contradicts Lemma 1 .

Lemma 4. Let $\left\{c_{t}, x_{t}, z_{t}\right\}_{t=1}^{T}$ be a solution path to the following problem:

$$
\max _{\left\{c_{t}, x_{t}, z_{t}\right\}_{t=1}^{T}} u\left(c_{1}\right)+\beta \sum_{\tau=1}^{T-1} \delta^{\tau} u\left(c_{1+\tau}\right)
$$

subject to

$$
\begin{aligned}
& x_{t}, z_{t} \geq 0 \quad \forall t \geq 1 \\
& c_{t} \leq y_{t}+R_{t} x_{t-1} \quad \forall t \geq 1 \\
& x_{t}+z_{t}=R_{t}\left(x_{t-1}+z_{t-1}\right)+y_{t}-c_{t} \quad \forall t \geq 1 \\
& x_{0}, z_{0} \text { fixed } \\
& x_{T}=z_{T}=0 \\
& \left\{c_{t}, x_{t}, z_{t}\right\}_{t=2}^{T} \text { satisfies } \mathrm{P} 1-\mathrm{P} 4 .
\end{aligned}
$$

Then $\left\{c_{t}, x_{t}, z_{t}\right\}_{t=1}^{T}$ satisfies P1-P4.

Proof of Lemma 4. The first step in the proof is to show that the solution set of the program above is a subset of the solution set of the program below.

$$
\max _{\left\{c_{t}, x_{t}, z_{t}\right\}_{t=1}^{T}} u\left(c_{1}\right)+\beta \sum_{\tau=1}^{T-1} \delta^{\tau} u\left(c_{1+\tau}\right)
$$

subject to

$$
\begin{aligned}
& x_{t}, z_{t} \geq 0 \quad \forall t \geq 1 \\
& c_{t} \leq y_{t}+R_{t} x_{t-1} \quad \forall t \geq 1 \\
& x_{t}+z_{t}=R_{t}\left(x_{t-1}+z_{t-1}\right)+y_{t}-c_{t} \quad \forall t \geq 1 \\
& x_{0}, z_{0} \text { fixed } \\
& x_{T}=z_{T}=0 \\
& c_{2} \geq y_{2} \\
& c_{t}=y_{t}+R_{t} x_{t-1} \quad \forall t \geq 3 .
\end{aligned}
$$

Henceforth I will refer to these, respectively, as program I and program II. Note that program II is a convex program with linear 
constraints, so the Kuhn-Tucker first-order conditions are necessary and sufficient for a global optimum. I will return to this fact later in the proof.

The following notation will be used to prove the lemma. Let $\Omega$ represent the set of all real vectors, $\omega=\left\{c_{t}, x_{t}, z_{t}\right\}_{t=1}^{T}$. Let $C_{I} \subset$ $\Omega\left(C_{I I} \subset \Omega\right)$ represent the subset of vectors in $\Omega$ which satisfy the constraints of program I (II). Let $C_{I}^{*} \subset \Omega\left(C_{I I}^{*} \subset \Omega\right)$ represent the subset of vectors in $\Omega$ that are solutions to program I (II).

The first step in the proof is to show that $C_{I} \subset C_{I I}$. Fix any $\omega$ $\in C_{I}$, and let $\omega=\left\{c_{t}, x_{t}, \mathrm{z}_{t}\right\}_{t=1}^{T}$. Note that the first five constraints of program I are identical to the first five constraints of program II. Also note that if $\left\{c_{t}, x_{t}, z_{t}\right\}_{t=2}^{T}$ satisfies P1-P4, then by Lemma $1, c_{2} \geq y_{2}$, and by Lemma $3, c_{t}=y_{t}+R_{t} x_{t-1} \forall t \geq 3$. Hence, $\omega \in$ $C_{I I}$, implying that $C_{I} \subset C_{I I}$.

The next step is to show $C_{I}^{*} \subset C_{I I}^{*}$. Fix any $\omega \in C_{I}^{*}$. Fix any $\omega^{\prime} \in C_{I I}^{*}$, and let $\omega^{\prime}=\left\{c_{t}, x_{t}, z_{t}\right\}_{t=1}^{T}$. Define $\hat{x}_{1}$ such that $c_{2}=y_{2}+$ $R_{2} \hat{x}_{1}$. Let $\omega^{\prime \prime}$ be equivalent to $\omega^{\prime}$ except that $x_{1}$ is replaced by $\hat{x}_{1}$, and $z_{1}$ is replaced by $\hat{z}_{1}=z_{1}-\left(\hat{x}_{1}-x_{1}\right)$. Let $U(\omega)$ represent the value of the objective function evaluated at $\omega$. Consider the following two properties of $\omega^{\prime \prime}: \omega^{\prime \prime} \in C_{I I}, U\left(\omega^{\prime}\right)=U\left(\omega^{\prime \prime}\right)$. Recall that $\omega^{\prime} \in C_{I I}^{*}$. Then $\omega^{\prime \prime}$ must also be an element of $C_{I I}^{*}$. Hence $\omega^{\prime \prime}$ must satisfy the Kuhn-Tucker conditions of program II (since the conditions are necessary and sufficient). Using the Kuhn-Tucker conditions and the definition of $\omega^{\prime \prime}$, it is straightforward to show that $\omega^{\prime \prime} \in C_{I}$. Note that $\omega^{\prime \prime} \in C_{I I}^{*}$ and $\omega \in C_{I}^{*} \subset \mathrm{C}_{I} \subset \mathrm{C}_{I I}$ imply that $U\left(\omega^{\prime \prime}\right) \geq U(\omega)$. Note that $\omega \in C_{I}^{*}$ and $\omega^{\prime \prime} \in C_{I}$ imply that $U\left(\omega^{\prime \prime}\right) \leq$ $U(\omega)$. Hence, $U(\omega)=U\left(\omega^{\prime \prime}\right)$, which implies that $U(\omega)=U\left(\omega^{\prime}\right)$. So $\omega^{\prime} \in C_{I I}^{*}$ and $\omega \in C_{I}^{*} \subset C_{I} \subset C_{I I}$ imply that $\omega \in C_{I I}^{*}$. Hence, $C_{I}^{*} \subset C_{I I}^{*}$

I am now ready to complete the proof of the lemma. Let $\omega$ be a solution to program I, and let $\omega=\left\{c_{t}, x_{t}, z_{t}\right\}_{t=1}^{T}$. So $\left\{c_{t}, x_{t}, z_{t}\right\}_{t=2}^{T}$ satisfies $\mathrm{P} 1-\mathrm{P} 4$. Since $C_{I}^{*} \subset C_{I I}^{*}, \omega$ must also satisfy the necessary and sufficient Kuhn-Tucker conditions of program II. Combining these constraints, it is straightforward to show that $\left\{c_{t}, x_{t}, z_{t}\right\}_{t=1}^{T}$ satisfies P1-P4.

Proof of Theorem 1. Suppose that there exist two resourceexhausting joint strategies, $s^{A}, s^{B} \in S$, that satisfy P1-P4. Fix any period $t$, and any feasible history $h_{t}$. Let $s^{A} \mid h_{t} \equiv$ $\left\{c_{t+\tau}^{A}, x_{t+\tau}^{A}, z_{t+\tau}^{A}\right\}_{\tau=0}^{T-t}, s^{B} \mid h_{t} \equiv\left\{c_{t+\tau}^{B}, x_{t+\tau}^{B}, z_{t+\tau}^{B}\right\}_{\tau=0}^{T-t}$. By resource exhaustion and Lemma 2, $c_{t+\tau}^{A}=c_{t+\tau}^{B} \forall \tau \geq 0$. Hence, by Lemma 3, $x$ ${ }_{t+\tau}^{A}=x_{t+\tau}^{B} \forall \tau \geq 0$. This in turn implies that $z_{t+\tau}^{A}=z_{t+\tau}^{B} \forall \tau \geq 0$, as 
a result of the savings constraints. Because the proof started with arbitary $h_{t}$, we can conclude that $s^{A}=s^{B}$ proving that there exists a unique resource-exhausting joint strategy, $s^{*} \in S$, that satisfies $\mathrm{P} 1-\mathrm{P} 4$. The second part of the theorem follows from this uniqueness result, Lemma 4, and a standard induction argument.

Proof of Proposition 1. If a steady state satisfies A1, then $\exp (\rho g) \geq R \delta$. Moreover, it is easy to construct a steady state at which $\exp (\rho g)=R \delta$. Suppose that there exists a steady state at which $\exp (\rho g)>R \delta$. Then by P1-P4, $\lim _{t \rightarrow \infty} z_{t}=\lim _{t \rightarrow \infty} x_{t}=0$, which implies that no such steady state could exist.

Proof of Proposition 2. By P1, $u^{\prime}\left(c_{t}\right) \geq \beta \delta^{\tau}\left(\Pi_{i=1}^{\tau} R_{t+i}\right) u^{\prime}\left(c_{t+\tau}\right) \forall$ $t \geq 2, \tau \geq 0$. Suppose that this inequality is satisfied exactly for some $t, \tau$ pair. Then $x_{t-1}=0$ by P3. Hence,

$$
\begin{aligned}
u^{\prime}\left(y_{t}\right) & =u^{\prime}\left(c_{t}\right) & & \text { by Lemma } 3 \\
& =\beta \delta^{\tau}\left(\prod_{i=1}^{\tau} R_{t+i}\right) u^{\prime}\left(c_{t+\tau}\right) & & \text { by assumption } \\
& \leq \beta \delta^{\tau}\left(\prod_{i=1}^{\tau} R_{t+i}\right) u^{\prime}\left(y_{t+\tau}\right) & & \text { by Lemma } 3 .
\end{aligned}
$$

But $u^{\prime}\left(y_{t}\right) \leq \beta \delta^{\tau}\left(\prod_{i=1}^{\tau} R_{t+i}\right) u^{\prime}\left(y_{t+\tau}\right)$ violates A1, (since A1 is assumed to hold strictly). So WLOG, assume that $u^{\prime}\left(c_{t}\right)>\beta \delta^{\tau}$ $\left(\Pi_{i=1}^{\tau} R_{t+i}\right) u^{\prime}\left(c_{t+\tau}\right) \forall t \geq 2, \tau \geq 0$. Hence, for sufficiently small $|\epsilon|$ $>0, u^{\prime}\left(c_{t}+\epsilon\right)>\beta \delta^{\tau}\left(\Pi_{i=1}^{\tau} R_{t+i}\right) u^{\prime}\left(c_{t+\tau}\right) \forall t \geq 2, \tau \geq 0$. So by P3 and the uniqueness result of Theorem 1 , in the subgame starting after any sufficiently small perturbation to the liquid asset stock, the equality $c_{t}=y_{t}+R_{t} x_{t-1}$ continues to hold, and hence, $\partial c_{t} /\left(\partial\left(R_{t}\right.\right.$ $\left.\left.x_{t-1}\right)\right)=1$.

Proof of Proposition 3. WLOG, assume that $u^{\prime}\left(c_{t}\right)>\beta \delta^{\tau}$ $\left(\prod_{i=1}^{\tau} R_{t+i}\right) u^{\prime}\left(c_{t+\tau}\right) \forall t \geq 2, \tau \geq 0$ (see Proof of Proposition 2). Hence, for sufficiently small $|\epsilon|>0, u^{\prime}\left(c_{t}\right)>\beta \delta^{\tau}\left(\prod_{i=1}^{\tau} R_{t+i}\right) u^{\prime}\left(c_{t+\tau}+\right.$ $\left.\left(\prod_{i=1}^{\tau} R_{i}\right) \epsilon\right) \forall t \geq 2, \tau \geq 0$. So current consumption does not change when $z_{t-1}$ is perturbed.

Proposition 4 is proved with two intermediate lemmas.

Lemma 5. Fix the economy described in Proposition 4. On the equilibrium path of this game $u^{\prime}\left(c_{t}\right)=(\delta R)^{\tau} u^{\prime}\left(c_{t+\tau}\right) \forall t \geq 2$.

Proof of Lemma 5. Suppose that $u^{\prime}\left(c_{t}\right)<(\delta R)^{\tau} u^{\prime}\left(c_{t+\tau}\right)$ for some $t \geq 2$. Then P3 implies $x_{t-1}=0$, implying that 


$$
\begin{aligned}
u^{\prime}\left(y_{t}\right) & =u^{\prime}\left(c_{t}\right) & & \text { by Lemma } 3 \\
& <(\delta R)^{\tau} u^{\prime}\left(c_{t+\tau}\right) & & \text { by assumption } \\
& \leq(\delta R)^{\tau} u^{\prime}\left(y_{t+\tau}\right) & & \text { by Lemma } 3 .
\end{aligned}
$$

Hence, $y_{t}^{-\rho}<(\delta R)^{\tau} y_{t+\tau}^{-\rho}$, implying that $\exp (\tau g) y_{t}>y_{t+\tau}$, which contradicts the assumptions of Proposition 4.

Alternatively, suppose that $u^{\prime}\left(c_{t}\right)>(\delta R)^{\tau} u^{\prime}\left(c_{t+\tau}\right)$ for some $t \geq$ 2. Then,

$$
\begin{aligned}
u^{\prime}\left(y_{t}\right) & \geq u^{\prime}\left(c_{t}\right) & & \text { by Lemma } 1 \\
& >(\delta R)^{\tau} u^{\prime}\left(c_{t+\tau}\right) & & \text { by assumption } \\
& =(\delta R)^{\tau} u^{\prime}\left(y_{t+\tau}+R x_{t+\tau-1}\right) & & \text { by Lemma } 3 .
\end{aligned}
$$

Note that $u^{\prime}\left(y_{t}\right)=(\delta R)^{\tau} u^{\prime}\left(y_{t+\tau}\right)$, follows from the assumptions. So the previous inequalities imply that $x_{t+\tau-1}>0$, which together with P3 implies that $u^{\prime}\left(c_{t+\tau}\right) \geq \sup _{n \geq 1}(\delta R)^{n} u^{\prime}\left(c_{t+\tau+n}\right)$. In addition, $x_{t+\tau-1}>0$, implies that $z_{t-1}>0$, which together with P4 implies that $u^{\prime}\left(c_{t}\right) \leq \sup _{n \geq 1}(\delta R)^{n} u^{\prime}\left(c_{t+n}\right)$. So there exists a finite $\hat{t} \in\{t+$ $1, t+2, \ldots, t+\tau-1\}$, such that $u^{\prime}\left(c_{\hat{t}}\right)>\sup _{n \geq 1}(\delta R)^{n} u^{\prime}\left(c_{\hat{t}+n}\right)$. Hence, by $\mathrm{P} 4, z_{\hat{t}-1}=0$, contradicting the result that $x_{t+\tau-1}>0$.

Lemma 6. Fix the economy described in Proposition 4. On the equilibrium path of this game $x_{t+\tau}=\exp (\tau g) x_{t}, z_{t+\tau}=$ $\exp (\tau g) z_{t}, \forall t \geq 1$.

Proof of Lemma 6. By Lemma 5, $u^{\prime}\left(c_{t}\right)=(\delta R)^{\tau} u^{\prime}\left(c_{t+\tau}\right) \forall t \geq$ 2. Combining this with Lemma 3 implies that $u^{\prime}\left(y_{t}+R x_{t-1}\right)$ $=(\delta R)^{\tau} u^{\prime}\left(y_{t+\tau}+R x_{t+\tau-1}\right)$. The assumptions, $\exp (\rho g)=\delta R$ and $y_{t+\tau}=\exp (\tau g) y_{t}$, can be used to simplify the previous equation, yielding, $x_{t+\tau-1}=\exp (\tau g) x_{t-1} \forall t \geq 2$. Note that resource exhaustion and Lemma 3 together imply that $z_{t}=\sum_{i=1}^{\infty} R^{-i} x_{t+i} \forall t \geq 1$. So $z_{t+\tau}=\sum_{i=1}^{\infty} R^{-i} x_{t+\tau+i}=\sum_{i=1}^{\infty} R^{-i} \exp (\tau g) x_{t+i}=\exp (\tau g) z_{t} \forall t \geq 1$.

Proof of Proposition 4. To prove this proposition, I consider two games: an original game, and a perturbed game. The perturbed game is identical to the original game except that in the perturbed game illiquid assets are higher at time zero. Let $\Delta a$ represent the difference between variable $a$ in the perturbed game and variable $a$ in the original game. Then Lemma 3 implies that

$$
\Delta z_{t+\tau-1}=R^{\tau}\left(\Delta z_{t-1}\right)\left(1-\frac{\Delta x_{t}}{\Delta\left(R z_{t-1}\right)}\right) \cdots\left(1-\frac{\Delta x_{t+\tau-1}}{\Delta\left(R z_{t+\tau-2}\right)}\right)
$$


for all $t \geq 2$. Hence,

$$
\begin{aligned}
1-M P C_{t}^{z} & =\lim _{\Delta z_{0} \rightarrow 0}\left[\left(1-\frac{\Delta x_{t}}{\Delta\left(R z_{t-1}\right)}\right) \cdots\left(1-\frac{\Delta x_{t+\tau-1}}{\Delta\left(R z_{t+\tau-2}\right)}\right)\right]^{1 / \tau} \\
& =\lim _{\Delta z_{0} \rightarrow 0}\left(\frac{\Delta z_{t+\tau-1}}{\Delta z_{t-1}}\right)^{1 / \tau} \frac{1}{R} \\
& =\frac{\exp (g)}{R} \\
& =\left(\delta R^{1-\rho}\right)^{1 / \rho}
\end{aligned}
$$

where the second to last equality follows from Lemma 6 .

Proof of Proposition 5. Laibson [1996] analyzes the economy without the commitment technology. I show that the infinite horizon equilibrium which corresponds to the limit of the finite horizon equilibria is characterized by constant proportional consumption of the wealth stock, where wealth is defined as the sum of financial assets and the discounted value of future labor income. Let $\lambda$ represent the coefficient of proportionality; I show that $\lambda$ is given by

$$
\lambda=1-\left[\delta R^{1-\rho}(\lambda(\beta-1)+1)\right]^{1 / \rho} .
$$

With proportional consumption the steady state condition is

$$
R(1-\lambda)=\exp (g) \text {. }
$$

Solving these equations to eliminate $\lambda$ yields equation (4).

Proof of Corollary to Proposition 5. Let $R^{*}$ represent the steady state gross interest rate in the economy with commitment. Recall Proposition 1: $\exp (\rho g)=\delta R^{*}$. Using Proposition 5, it follows that $R-R^{*}=(r-g)(1-\beta)>0$ as $r>g$ is required for the existence of a steady state.

HARVARD UNIVERSITY

\section{REFERENCES}

Ainslie, George W., "Specious Reward: A Behavioral Theory of Impulsiveness and Impulsive Control," Psychological Bulletin, LXXXII (1975), 463-96.

, "Beyond Microeconomics. Conflict among Interests in a Multiple Self as a Determinant of Value." in The Multiple Self, Jon Elster, ed. (Cambridge, UK: Cambridge University Press, 1986).

_, Picoeconomics (Cambridge, UK: Cambridge University Press, 1992).

Aiyagari, S. Rao, "Uninsured Idiosyncratic Risk and Aggregate Saving," Working Paper 502, Federal Reserve Bank of Minneapolis, 1992. 
Akerlof, George, "Procrastination and Obedience," American Economic Review, LXXXI (1991), 1-19.

Attanasio, Orazio P., and Guglielmo Weber, "Consumption Growth, the Interest Rate, and Aggregation," Review of Economic Studies, LX (1993), 631-49.

Board of Governors of the Federal Reserve System, Balance Sheets for the U. S. Economy 1945-94 (Washington, DC: 1995).

Canner, Glenn B., and Charles A. Luckett, "Developments in the Pricing of Credit Card Services," Federal Reserve Bulletin, LXXVIII (1992), 652-66.

Canner, Glenn B., and Charles A. Luckett, "Home Equity Lending: Evidence from Recent Surveys," Federal Reserve Bulletin, LXXX (1994), 571-83.

Carroll, Christopher D., "The Buffer-Stock Theory of Saving: Some Macroeconomic Evidence," Brookings Papers on Economics Activity (1992:2), 61-156.

_- "How Does Future Income Affect Current Consumption?" Board of Governors of the Federal Reserve System, 1992.

Carroll, Christopher D., and Lawrence H. Summers, "Consumption Growth Parallels Income Growth: Some New Evidence," in National Saving and Economic Performance, B. Douglas Bernheim and John Shoven, eds. (Chicago, IL: Chicago University Press, 1991).

Chung, Shin-Ho, and Richard J. Herrnstein, "Relative and Absolute Strengths of Response as a Function of Frequency of Reinforcement," Journal of the Experimental Analysis of Animal Behavior, IV (1961), 267-72.

Farnsworth, E. Allan, Contracts (Boston, MA: Little, Brown and Company, 1990).

Flavin, Marjorie, "The Joint Consumption/Asset Demand Decision: A Case Study in Robust Estimation," NBER Working Paper No. 3802, 1991.

Goetz, Charles J., and Robert E. Scott, "Liquidated Damages, Penalties and the Just Compensation Principle: Some Notes on an Enforcement Model and a Theory of Efficient Breach," Columbia Law Review, LXXVII (1977), 554-94.

Goldman, Steven M., "Consistent Plans," Review of Economic Studies, XLVII (1980), 533-37.

Gourinchas, Pierre-Olivier, and Jonathan Parker, "Consumption over the LifeCycle," MIT mimeo, 1995.

Hall, Robert E., and Frederic S. Mishkin, "The Sensitivity of Consumption to Transitory Income: Estimates from Panel Data on Households," Econometrica, L (1982), 461-81.

Hatsopoulos, George N., Paul R. Krugman, James M. Poterba, "Overconsumption: The Challenge to U. S. Economic Policy," American Business Conference Working Paper, 1989.

Laibson, David I., "Notes on a Commitment Problem," MIT mimeo, 1993.

, "Self-Control and Saving," MIT mimeo, 1994a.

_-, "An Intrapersonal Principal-Agent Problem," MIT mimeo, 1994b.

_-, "Hyperbolic Discounting, Undersaving, and Savings Policy," NBER Working Paper No. 5635, 1996.

Loewenstein, George, and Drazen Prelec, "Anomalies in Intertemporal Choice: Evidence and an Interpretation," Quarterly Journal of Economics, CVII (1992), 573-98.

Mandell, Lewis, The Credit Card Industry (Boston, MA: Twayne Publishers, 1990).

Peleg, Bezalel, and Menahem E. Yaari, "On the Existence of a Consistent Course of Action When Tastes Are Changing," Review of Economic Studies, XL (1973), 391-401.

Phelps, E. S., and R. A. Pollak, "On Second-Best National Saving and GameEquilibrium Growth," Review of Economic Studies, XXXV (1968), 185-99.

Pollak, R. A., "Consistent Planning," Review of Economic Studies, XXXV (1968), 201-08.

Prelec, Drazen, "Decreasing Impatience: Definition and Consequences," Harvard Business School Working Paper, 1989.

Rankin, Deborah M., "How to Get Ready for Retirement: Save, Save Save," New York Times, March 13, 1993, p. 33.

Rea, Samuel A., Jr., "Efficiency Implications of Penalties and Liquidated Damages," Journal of Legal Studies, XIII (1984), 147-67.

Runkle, David E., "Liquidity Constraints and the Permanent-Income Hypothesis," Journal of Monetary Economics, XXVII (1991), 73-98.

Shea, John, "Union Contracts and the Life Cycle/Permanent-Income Hypothesis," American Economic Review, LXXXV (1995), 186-200. 
Souleles, Nicholas, "The Response of Household Consumption to Income Tax Refunds," MIT mimeo, 1995.

Strotz, Robert H., "Myopia and Inconsistency in Dynamic Utility Maximization," Review of Economic Studies, XXIII (1956), 165-80.

Thaler, Richard H., "Saving, Fungibility, and Mental Accounts," Journal of Economic Perspectives, IV (1990), 193-205.

Zeckhauser, Richard, and Stephen Fels, "Discounting for Proximity with Perfect and Total Altruism," Harvard Institute of Economic Research, Discussion Paper No. 50, 1968.

Zeldes, Stephen P., "Consumption and Liquidity Constraints: An Empirical Investigation," Journal of Political Economy, XCVII (1989), 305-46. 


\section{This article has been cited by:}

1. Daniel Houser. 2010. A Note on Norms in Experimental Economics. Eastern Economic Journal 34:1, 126-128. [CrossRef]

2. Isabelle Brocas. 2009. Dynamic inconsistency and choice. Theory and Decision . [CrossRef]

3. Matthias Wrede. 2009. Hyperbolic discounting and fertility. Journal of Population Economics . [CrossRef]

4. Anthony Patt, Nicole Peterson, Michael Carter, Maria Velez, Ulrich Hess, Pablo Suarez. 2009. Making index insurance attractive to farmers. Mitigation and Adaptation Strategies for Global Change . [CrossRef]

5. Amanda Swift King, John T. King. 2009. Golden eggs versus plastic eggs: hyperbolic preferences and the persistence of debit. Journal of Economics and Finance . [CrossRef]

6. Abhinay Muthoo, Kenneth A. Shepsle. 2009. Information, institutions and constitutional arrangements. Public Choice . [CrossRef]

7. Yonatan Loewenstein, Drazen Prelec, H. Sebastian Seung. 2009. Operant Matching as a Nash Equilibrium of an Intertemporal GameOperant Matching as a Nash Equilibrium of an Intertemporal Game. Neural Computation 21:10, 2755-2773. [Abstract] [Full Text] [PDF] [PDF Plus]

8. Bassem Ben Halima, Mohamed Ali Ben Halima. 2009. Time Preferences and Job Search: Evidence from France. LABOUR 23:3, 535-558. [CrossRef]

9. Francis A Longstaff. 2009. Portfolio Claustrophobia: Asset Pricing in Markets with Illiquid Assets. American Economic Review 99:4, 1119-1144. [CrossRef]

10. Giovanni Mastrobuoni, Matthew Weinberg. 2009. Heterogeneity in Intra-Monthly Consumption Patterns, Self-Control, and Savings at Retirement. American Economic Journal: Economic Policy 1:2, 163-189. [CrossRef]

11. Mohammed Abdellaoui, Arthur E. Attema, Han Bleichrodt. 2009. Intertemporal Tradeoffs for Gains and Losses: An Experimental Measurement of Discounted Utility. The Economic Journal . [CrossRef]

12. T. Scott Findley, Frank N. Caliendo. 2009. Short horizons, time inconsistency, and optimal social security. International Tax and Public Finance 16:4, 487-513. [CrossRef]

13. Yusuke Kinari, Fumio Ohtake, Yoshiro Tsutsui. 2009. Time discounting: Declining impatience and interval effect. Journal of Risk and Uncertainty 39:1, 87-112. [CrossRef]

14. Gal Zauberman, B. Kyu Kim, Selin A Malkoc, James R Bettman. 2009. Discounting Time and Time Discounting: Subjective Time Perception and Intertemporal Preferences. Journal of Marketing Research 46:4, 543-556. [CrossRef] 
15. A. S. Nowak. 2009. On a Noncooperative Stochastic Game Played by Internally Cooperating Generations. Journal of Optimization Theory and Applications . [CrossRef]

16. Botond Köszegi, Matthew Rabin. 2009. Reference-Dependent Consumption Plans. American Economic Review 99:3, 909-936. [CrossRef]

17. Stefano DellaVigna. 2009. Psychology and Economics: Evidence from the Field. Journal of Economic Literature 47:2, 315-372. [CrossRef]

18. C. Leigh ANDERSON, Mary Kay GUGERTY. 2009. INTERTEMPORAL CHOICE AND DEVELOPMENT POLICY: NEW EVIDENCE ON TIME-VARYING DISCOUNT RATES FROM VIETNAM AND RUSSIA. The Developing Economies 47:2, 123-146. [CrossRef]

19. Nick Netzer. 2009. Evolution of Time Preferences and Attitudes toward Risk. American Economic Review 99:3, 937-955. [CrossRef]

20. Linda G. Martin. 2009. Interventions to Improve Late Life. Population and Development Review 35:2, 331-340. [CrossRef]

21. S. V. Burks, J. P. Carpenter, L. Goette, A. Rustichini. 2009. Cognitive skills affect economic preferences, strategic behavior, and job attachment. Proceedings of the National Academy of Sciences 106:19, 7745-7750. [CrossRef]

22. Alessandro Tarozzi, Aprajit Mahajan, Joanne Yoong, Brian Blackburn. 2009. Commitment Mechanisms and Compliance with Health-Protecting Behavior: Preliminary Evidence from Orissa, India. American Economic Review 99:2, 231-235. [CrossRef]

23. Botond Köszegi. 2009. Utility from anticipation and personal equilibrium. Economic Theory . [CrossRef]

24. Jeremy Tobacman. 2009. Endogenous Effective Discounting, Credit Constraints, and Wealth Inequality. American Economic Review 99:2, 369-373. [CrossRef]

25. Shantanu Bagchi. 2009. Can overconfidence explain the consumption hump?. Journal of Economics and Finance. [CrossRef]

26. Henk Folmer. 2009. Why Sociology is Better Conditioned to Explain Economic Behaviour than Economics. Kyklos 62:2, 258-274. [CrossRef]

27. Marco Casari. 2009. Pre-commitment and flexibility in a time decision experiment. Journal of Risk and Uncertainty 38:2, 117-141. [CrossRef]

28. Paul Heidhues , Botond Kőszegi . 2009. Futile Attempts at Self-ControlFutile Attempts at Self-Control. Journal of the European Economic Association 7:2-3, 423-434. [Abstract] [PDF] [PDF Plus]

29. B. Douglas Bernheim . 2009. Behavioral Welfare EconomicsBehavioral Welfare Economics. Journal of the European Economic Association 7:2-3, 267-319. [Abstract] [PDF] [PDF Plus]

30. Kaisa Kotakorpi. 2009. Paternalism and Tax Competition. Scandinavian Journal of Economics 111:1, 125-149. [CrossRef] 
31. Robert L. Scharff. 2009. Obesity and Hyperbolic Discounting: Evidence and Implications. Journal of Consumer Policy 32:1, 3-21. [CrossRef]

32. Michael Dothan, Fred Thompson. 2009. A better budget rule. Journal of Policy Analysis and Management 28:3, 463-478. [CrossRef]

33. Christopher Mayer, Karen Pence, Shane M Sherlund. 2009. The Rise in Mortgage Defaults. Journal of Economic Perspectives 23:1, 27-50. [CrossRef]

34. B. Douglas Bernheim, Antonio Rangel. 2009. Beyond Revealed Preference: Choice-Theoretic Foundations for Behavioral Welfare Economics*Beyond Revealed Preference: Choice-Theoretic Foundations for Behavioral Welfare Economics*. Quarterly Journal of Economics 124:1, 51-104. [Abstract] [PDF] [PDF Plus]

35. Alexander L. Brown, Zhikang Eric Chua, Colin F. Camerer. 2009. Learning and Visceral Temptation in Dynamic Saving Experiments*Learning and Visceral Temptation in Dynamic Saving Experiments*. Quarterly Journal of Economics 124:1, 197-231. [Abstract] [PDF] [PDF Plus] [Supplementary material]

36. Brigitte Fünfgeld, Mei Wang. 2009. Attitudes and behaviour in everyday finance: evidence from Switzerland. International Journal of Bank Marketing 27:2, 108-128. [CrossRef]

37. Elke U. Weber, Eric J. Johnson. 2009. Mindful Judgment and Decision Making. Annual Review of Psychology 60:1, 53-85. [CrossRef]

38. Emir Kamenica. 2009. Contextual Inference in Markets: On the Informational Content of Product Lines. American Economic Review 98:5, 2127-2149. [CrossRef]

39. Christopher F. Chabris, David Laibson, Carrie L. Morris, Jonathon P. Schuldt, Dmitry Taubinsky. 2009. Individual laboratory-measured discount rates predict field behavior. Journal of Risk and Uncertainty 37:2-3, 237-269. [CrossRef]

40. Randall P. Ellis, Elizabeth Savage. 2009. Run for cover now or later? The impact of premiums, threats and deadlines on private health insurance in Australia. International Journal of Health Care Finance and Economics 8:4, 257-277. [CrossRef]

41. W. Kip Viscusi, Joel Huber, Jason Bell. 2009. Estimating discount rates for environmental quality from utility-based choice experiments. Journal of Risk and Uncertainty 37:2-3, 199-220. [CrossRef]

42. H. Ersner-Hershfield, G. E. Wimmer, B. Knutson. 2008. Saving for the future self: Neural measures of future self-continuity predict temporal discounting. Social Cognitive and Affective Neuroscience 4:1, 85-92. [CrossRef]

43. Abigail Barr , Garance Genicot . 2008. Risk Sharing, Commitment, and Information: An Experimental AnalysisRisk Sharing, Commitment, and Information: An Experimental Analysis. Journal of the European Economic Association 6:6, 1151-1185. [Abstract] [PDF] [PDF Plus]

44. Ferdinando Colombo, Guido Merzoni. 2008. For how long to tie your hands? Stable relationships in an unstable environment. Journal of Economics 95:2, 93-120. [CrossRef] 
45. David M Cutler. 2008. Are We Finally Winning the War on Cancer?. Journal of Economic Perspectives 22:4, 3-26. [CrossRef]

46. Camillo Padoa-Schioppa. 2008. THE SYLLOGISM OF NEURO-ECONOMICS. Economics and Philosopby 24:03, 449. [CrossRef]

47. Bernd Huber, Marco Runkel. 2008. HYPERBOLIC DISCOUNTING, PUBLIC DEBT AND BALANCED BUDGET RULES. Scottish Journal of Political Economy 55:5, 543-560. [CrossRef]

48. Jukka Pirttilä, Sanna Tenhunen. 2008. Pawns and queens revisited: public provision of private goods when individuals make mistakes. International Tax and Public Finance 15:5, 599-619. [CrossRef]

49. Isabelle Brocas, Juan D Carrillo. 2008. The Brain as a Hierarchical Organization. American Economic Review 98:4, 1312-1346. [CrossRef]

50. Jonathan Gruber. 2008. Covering the Uninsured in the United States. Journal of Economic Literature 46:3, 571-606. [CrossRef]

51. Juan D. Carrillo, Mathias Dewatripont. 2008. Promises, Promises, ...*. The Economic Journal 118:531, 1453-1473. [CrossRef]

52. Eugene M. Caruso, Daniel T. Gilbert, Timothy D. Wilson. 2008. A Wrinkle in Time: Asymmetric Valuation of Past and Future Events. Psychological Science 19:8, 796-801. [CrossRef]

53. DANIEL GOTTLIEB. 2008. Competition over Time-Inconsistent Consumers. Journal of Public Economic Theory 10:4, 673-684. [CrossRef]

54. M. Daniele Paserman. 2008. Job Search and Hyperbolic Discounting: Structural Estimation and Policy Evaluation*. The Economic Journal 118:531, 1418-1452. [CrossRef]

55. Ivar Ekeland, Traian A. Pirvu. 2008. Investment and consumption without commitment. Mathematics and Financial Economics 2:1, 57-86. [CrossRef]

56. PAUL KLEIN, PER KRUSELL, JOSÉ-VÍCTOR RÍOS-RULL. 2008. Time-Consistent Public Policy. Review of Economic Studies 75:3, 789-808. [CrossRef]

57. MICHAEL R. CAPUTO. 2008. THE INTRINSIC QUALITATIVE PROPERTIES OF THE CLASSICAL OPTIMAL STOPPING PROBLEM ARE INVARIANT TO THE FUNCTIONAL FORM OF THE DISCOUNT FUNCTION. Natural Resource Modelling · [CrossRef]

58. Yoram Halevy. 2008. Strotz Meets Allais: Diminishing Impatience and the Certainty Effect. American Economic Review 98:3, 1145-1162. [CrossRef]

59. Ani Guerdjikova, Alexander Zimper. 2008. Flexibility of choice versus reduction of ambiguity. Social Choice and Welfare 30:3, 507-526. [CrossRef]

60. Amihai Glazer. 2008. Social security and conflict within the family. Journal of Population Economics 21:2, 331-338. [CrossRef] 
61. W. Troy Tucker, Scott Ferson. 2008. Evolved Altruism, Strong Reciprocity, and Perception of Risk. Annals of the New York Academy of Sciences 1128:1, 111-120. [CrossRef]

62. Enrica Carbone. 2008. Temptations and Dynamic Consistency. Theory and Decision 64:2-3, 229-248. [CrossRef]

63. Jianjun Miao. 2008. Option exercise with temptation. Economic Theory 34:3, 473-501. [CrossRef]

64. Benjamin E. Hermalin, Alice M. Isen. 2008. A model of the effect of affect on economic decision making. Quantitative Marketing and Economics 6:1, 17-40. [CrossRef]

65. LIAM GRAHAM, DENNIS J. SNOWER. 2008. Hyperbolic Discounting and the Phillips Curve. Journal of Money, Credit and Banking 40:2-3, 427-448. [CrossRef]

66. Hiroshi Fujiu, Makoto Yano. 2008. Altruism as a motive for intergenerational transfers. International Journal of Economic Theory 4:1, 95-114. [CrossRef]

67. Michelle J White. 2008. Bankruptcy Reform and Credit Cards. Journal of Economic Perspectives 21:4, 175-199. [CrossRef]

68. Michael A. Salinger, Pauline M. Ippolito, Joel L. Schrag. 2007. Economics at the FTC: Pharmaceutical Patent Dispute Settlements and Behavioral Economics. Review of Industrial Organization 31:2, 85-105. [CrossRef]

69. Kirsten I. M. Rohde. 2007. Arbitrage opportunities in frictionless markets with sophisticated investors. Economic Theory 34:2, 389-393. [CrossRef]

70. Scott Beaulier, Bryan Caplan. 2007. Behavioral Economics and Perverse Effects of the Welfare State. Kyklos 60:4, 485-507. [CrossRef]

71. Wei-Yin Hu, Jason S. Scott. 2007. Behavioral Obstacles in the Annuity Market. Financial Analysts Journal 63:6, 71-82. [CrossRef]

72. Yih-Luan Chyi, Yu-Lun Liu. 2007. Income Uncertainty and Wealth Accumulation: How Precautionary are Taiwanese Households?. Asian Economic Journal 21:3, 301-319. [CrossRef]

73. CAITLIN ZALOOM. 2007. Future knowledge. American Ethnologist 34:3, 444-446. [CrossRef]

74. Daniel R. Burghart, Trudy Ann Cameron, Geoffrey R. Gerdes. 2007. Valuing publicly sponsored research projects: Risks, scenario adjustments, and inattention. Journal of Risk and Uncertainty 35:1, 77-105. [CrossRef]

75. Herbert Gintis. 2007. Review 2 Economic Growth and Wellbeing: A Behavioural Analysis. The Economic Journal 117:521, 455-459. [CrossRef]

76. John Ameriks, Andrew Caplin, John Leahy, Tom Tyler. 2007. Measuring Self-Control Problems. American Economic Review 97:3, 966-972. [CrossRef]

77. Keith Hayward. 2007. Situational Crime Prevention and its Discontents: Rational Choice Theory versus the ?Culture of Now?. Social Policy \& Administration 41:3, 232-250. [CrossRef] 
78. Marc Wittmann, David S. Leland, Martin P. Paulus. 2007. Time and decision making: differential contribution of the posterior insular cortex and the striatum during a delay discounting task. Experimental Brain Research 179:4, 643-653. [CrossRef]

79. Edmund S Phelps. 2007. Macroeconomics for a Modern Economy. American Economic Review 97:3, 543-561. [CrossRef]

80. Paul William Glimcher, Joseph Kable, Kenway Louie. 2007. Neuroeconomic Studies of Impulsivity: Now or Just as Soon as Possible?. American Economic Review 97:2, 142-147. [CrossRef]

81. Raj Chetty, Adam Szeidl. 2007. Consumption Commitments and Risk Preferences*Consumption Commitments and Risk Preferences*. Quarterly Journal of Economics 122:2, 831-877. [Abstract] [PDF] [PDF Plus]

82. ALAIN AYONG LE KAMA, KATHELINE SCHUBERT. 2007. A NOTE ON THE CONSEQUENCES OF AN ENDOGENOUS DISCOUNTING DEPENDING ON THE ENVIRONMENTAL QUALITY. Macroeconomic Dynamics 11:02. . [CrossRef]

83. Fredric Jacobsson, Magnus Johannesson, Lars Borgquist. 2007. Is Altruism Paternalistic?. The Economic Journal 117:520, 761-781. [CrossRef]

84. George A Akerlof. 2007. The Missing Motivation in Macroeconomics. American Economic Review 97:1, 5-36. [CrossRef]

85. Alexander Gattig, Laurie Hendrickx. 2007. Judgmental Discounting and Environmental Risk Perception: Dimensional Similarities, Domain Differences, and Implications for Sustainability. Journal of Social Issues 63:1, 21-39. [CrossRef]

86. Colin F. Camerer. 2007. Neuroeconomics: Using Neuroscience to Make Economic Predictions. The Economic Journal 117:519, C26-C42. [CrossRef]

87. Mary Kay Gugerty. 2007. You Can't Save Alone: Commitment in Rotating Savings and Credit Associations in Kenya. Economic Development and Cultural Change 55:2, 251-282. [CrossRef]

88. FARUK GUL, WOLFGANG PESENDORFER. 2007. Harmful Addiction. Review of Economic Studies 74:1, 147-172. [CrossRef]

89. Drew Fudenberg, David K Levine. 2007. A Dual-Self Model of Impulse Control. American Economic Review 96:5, 1449-1476. [CrossRef]

90. Marina Azzimonti, Eva de Francisco, Per Krusell. 2007. Median-voter Equilibria in the Neoclassical Growth Model under Aggregation. Scandinavian Journal of Economics 108:4, 587-606. [CrossRef]

91. Jeremy Clark, Bonggeun Kim, Richie Poulton, Barry Milne. 2006. The role of low expectations in health and education investment and hazardous consumption. Canadian Journal of Economics/Revue canadienne d'economique 39:4, 1151-1172. [CrossRef] 
92. Antoine Bommier. 2006. UNCERTAIN LIFETIME AND INTERTEMPORAL CHOICE: RISK AVERSION AS A RATIONALE FOR TIME DISCOUNTING. International Economic Review 47:4, 1223-1246. [CrossRef]

93. Selin A Malkoc, Gal Zauberman. 2006. Deferring Versus Expediting Consumption: The Effect of Outcome Concreteness on Sensitivity to Time Horizon. Journal of Marketing Research 43:4, 618-627. [CrossRef]

94. Botond Köszegi, Matthew Rabin. 2006. A Model of Reference-Dependent Preferences*A Model of Reference-Dependent Preferences*. Quarterly Journal of Economics 121:4, 1133-1165. [Abstract] [PDF] [PDF Plus]

95. P. Jean-Jacques Herings, Kirsten I. M. Rohde. 2006. Time-inconsistent preferences in a general equilibrium model. Economic Theory 29:3, 591-619. [CrossRef]

96. Wolfgang Pesendorfer. 2006. Behavioral Economics Comes of Age: A Review Essay on Advances in Behavioral Economics. Journal of Economic Literature 44:3, 712-721. [CrossRef]

97.JOSEPH HEATH. 2006. The Benefits of Cooperation. Philosophy <btml_ent glyph="@amp;" ascii="Jamp;"/> Public Affairs 34:4, 313-351. [CrossRef]

98. Marc Scholten, Daniel Read. 2006. Discounting by Intervals: A Generalized Model of Intertemporal Choice. Management Science 52:9, 1424-1436. [CrossRef]

99. Drew Fudenberg. 2006. Advancing Beyond Advances in Behavioral Economics. Journal of Economic Literature 44:3, 694-711. [CrossRef]

100. Michael L. Stern. 2006. Endogenous time preference and optimal growth. Economic Theory 29:1, 49-70. [CrossRef]

101. W. Kip Viscusi, Richard J. Zeckhauser. 2006. The Perception and Valuation of the Risks of Climate Change: A Rational and Behavioral Blend. Climatic Change 77:1-2, 151-177. [CrossRef]

102. Elke U. Weber. 2006. Experience-Based and Description-Based Perceptions of Long-Term Risk: Why Global Warming does not Scare us (Yet). Climatic Change 77:1-2, 103-120. [CrossRef]

103. Drazen Prelec. 2006. Rebuilding the Boat While Staying Afloat: The Modeling Challenge for Behavioral Economics. Journal of Marketing Research 43:3, 332-336. [CrossRef]

104. Y. Hossein Farzin. 2006. Conditions for Sustainable Optimal Economic Development. Review of Development Economics 10:3, 518-534. [CrossRef]

105. Teck H Ho, Noah Lim, Colin F Camerer. 2006. Modeling the Psychology of Consumer and Firm Behavior with Behavioral Economics. Journal of Marketing Research 43:3, 307-331. [CrossRef]

106. P. Read Montague, Brooks King-Casas, Jonathan D. Cohen. 2006. IMAGING VALUATION MODELS IN HUMAN CHOICE. Annual Review of Neuroscience 29:1, 417-448. [CrossRef]

107. Melvin Stephens. 2006. Paycheque Receipt and the Timing of Consumption. The Economic Journal 116:513, 680-701. [CrossRef] 
108. James H. Fowler, Cindy D. Kam. 2006. Patience as a Political Virtue: Delayed Gratification and Turnout. Political Behavior 28:2, 113-128. [CrossRef]

109. LIVIO STRACCA. 2006. A NOTE ON LIQUIDITY AND REAL EQUILIBRIUM INTEREST RATES. Macroeconomic Dynamics 10:03. . [CrossRef]

110. Luigi Guiso, Paola Sapienza, Luigi Zingales. 2006. Does Culture Affect Economic Outcomes?. Journal of Economic Perspectives 20:2, 23-48. [CrossRef]

111. Nava Ashraf, Dean Karlan, Wesley Yin. 2006. Tying Odysseus to the Mast: Evidence from a Commitment Savings Product in the Philippines*Tying Odysseus to the Mast: Evidence from a Commitment Savings Product in the Philippines*. Quarterly Journal of Economics 121:2, 635-672. [Abstract] [PDF] [PDF Plus]

112. LARRY G. EPSTEIN. 2006. An Axiomatic Model of Non-Bayesian Updating. Review of Economic Studies 73:2, 413-436. [CrossRef]

113. Manuel Amador, Ivan Werning, George-Marios Angeletos. 2006. Commitment vs. Flexibility. Econometrica 74:2, 365-396. [CrossRef]

114. Ezra W. Zuckerman, Stoyan V. Sgourev. 2006. Peer Capitalism: Parallel Relationships in the U.S. Economy. American Journal of Sociology 111:5, 1327-1366. [CrossRef]

115. Andrew Yuengert. 2006. Model selection and multiple research goals: The case of rational addiction. Journal of Economic Methodology 13:1, 77-96. [CrossRef]

116. Rafael Di Tella, Robert MacCulloch. 2006. Some Uses of Happiness Data in Economics. Journal of Economic Perspectives 20:1, 25-46. [CrossRef]

117. Tullio Jappelli , Luigi Pistaferri . 2006. Intertemporal Choice and Consumption MobilityIntertemporal Choice and Consumption Mobility. Journal of the European Economic Association 4:1, 75-115. [Abstract] [PDF] [PDF Plus]

118. Philip Oreopoulos. 2006. The compelling effects of compulsory schooling: evidence from Canada. Canadian Journal of Economics/Revue canadienne dorapos; <btml_ent glyph="@eacute;" ascii="e"/>conomique 39:1, 22-52. [CrossRef]

119. N. Schweighofer, K. Shishida, C. E. Han, Y. Okamoto, S. C. Tanaka, S. Yamawaki, K. Doya. 2006. Humans Can Adopt Optimal Discounting Strategy under Real-Time Constraints. PLoS Computational Biology 2:11, e152. [CrossRef]

120. Marco K.W. Yu. 2006. The social discount rate on climate change: A case study of Part L of Schedule 1 of the UK Building Regulations - conservation of fuel and power. Property Management 24:2, 144-161. [CrossRef]

121. John G Lynch, Gal Zauberman. 2006. When Do You Want It? Time, Decisions, and Public Policy. Journal of Public Policy \& Marketing 25:1, 67-78. [CrossRef]

122. Tülin Erdem, Kannan Srinivasan, Wilfred Amaldoss, Patrick Bajari, Hai Che, Teck Ho, Wes Hutchinson, Michael Katz, Michael Keane, Robert Meyer, Peter Reiss. 2006. Theory-Driven Choice Models. Marketing Letters 16:3-4, 225-237. [CrossRef] 
123. Jonathan D Cohen. 2006. The Vulcanization of the Human Brain: A Neural Perspective on Interactions Between Cognition and Emotion. Journal of Economic Perspectives 19:4, 3-24. [CrossRef]

124. On Amir, Dan Ariely, Alan Cooke, David Dunning, Nicholas Epley, Uri Gneezy, Botond Koszegi, Donald Lichtenstein, Nina Mazar, Sendhil Mullainathan, Drazen Prelec, Eldar Shafir, Jose Silva. 2006. Psychology, Behavioral Economics, and Public Policy. Marketing Letters 16:3-4, 443-454. [CrossRef]

125. Dilip Soman, George Ainslie, Shane Frederick, Xiuping Li, John Lynch, Page Moreau, Andrew Mitchell, Daniel Read, Alan Sawyer, Yaacov Trope, Klaus Wertenbroch, Gal Zauberman. 2006. The Psychology of Intertemporal Discounting: Why are Distant Events Valued Differently from Proximal Ones?. Marketing Letters 16:3-4, 347-360. [CrossRef]

126. Ben Groom, Cameron Hepburn, Phoebe Koundouri, David Pearce. 2006. Declining Discount Rates: The Long and the Short of it. Environmental \& Resource Economics 32:4, 445-493. [CrossRef]

127. Axel Borsch-Supan. 2005. Risiken im Lebenszyklus: Theorie und Evidenz. Perspektiven der Wirtschaftspolitik 6:4, 449-469. [CrossRef]

128. Mark A. Moore, Anthony E. Boardman, Aidan R. Vining, David L. Weimer, David H. Greenberg. 2005. ?Just give me a number!? Practical values for the social discount rate. Journal of Policy Analysis and Management 23:4, 789-812. [CrossRef]

129. Lilia Maliar, Serguei Maliar. 2005. Solving the Neoclassical Growth Model with Quasi-Geometric Discounting: A Grid-Based Euler-Equation Method. Computational Economics 26:2, 163-172. [CrossRef]

130. Nava Ashraf, Colin F Camerer, George Loewenstein. 2005. Adam Smith, Behavioral Economist. Journal of Economic Perspectives 19:3, 131-145. [CrossRef]

131. THERESE JEFFERSON. 2005. Women and Retirement Incomes in Australia: A Review*. Economic Record 81:254, 273-291. [CrossRef]

132. Joni Hersch. 2005. Smoking Restrictions as a Self-Control Mechanism. Journal of Risk and Uncertainty 31:1, 5-21. [CrossRef]

133. Nikolay Gospodinov, Ian Irvine. 2005. A 'long march' perspective on tobacco use in Canada. Canadian Journal of Economics/Revue Canadienne d'Economique 38:2, 366-393. [CrossRef]

134. Eric A. Finkelstein, Christopher J. Ruhm, Katherine M. Kosa. 2005. ECONOMIC CAUSES AND CONSEQUENCES OF OBESITY. Annual Review of Public Health 26:1, 239-257. [CrossRef]

135. Faruk Gul, Wolfgang Pesendorfer. 2005. The Revealed Preference Theory of Changing Tastes. Review of Economic Studies 72:2, 429-448. [CrossRef]

136. Orla Gough, Peter D. Sozou. 2005. Pensions and retirement savings: cluster analysis of consumer behaviour and attitudes. International Journal of Bank Marketing 23:7, 558-570. [CrossRef] 
137. Gal Zauberman, John G., Jr. Lynch. 2005. Resource Slack and Propensity to Discount Delayed Investments of Time Versus Money. Journal of Experimental Psychology: General 134:1, 23-37. [CrossRef]

138. Yasuhisa HAYASHIYAMA, Masakazu INAGAKI, Kazuya SAKATA. 2005. THE LONG-TERM EFFECT OF ENVIRONMENTAL EDUCATION IN PRESENT-BIASED PREFERENCE SOME KNOWLEDGE BY THE NUMERICAL ANALYSIS. Doboku Gakkai Ronbunshu :797, 25-36. [CrossRef]

139. Daniel S. Nagin, Greg Pogarsky. 2005. Time and Punishment: Delayed Consequences and Criminal Behavior. Journal of Quantitative Criminology 20:4, 295-317. [CrossRef]

140. Andrew Caplin, John Leahy. 2005. The Social Discount Rate. Journal of Political Economy 112:6, 1257-1268. [CrossRef]

141. Drazen Prelec. 2004. Decreasing Impatience: A Criterion for Non-stationary Time Preference and "Hyperbolic" Discounting. Scandinavian Journal of Economics 106:3, 511-532. [CrossRef]

142. David T. Chau, Robert M. Roth, Alan I. Green. 2004. The neural circuitry of reward and its relevance to psychiatric disorders. Current Psychiatry Reports 6:5, 391-399. [CrossRef]

143. Roland Bénabou, Jean Tirole. 2004. Willpower and Personal Rules. Journal of Political Economy 112:4, 848-886. [CrossRef]

144. C. Leigh Anderson, Maya Dietz, Andrew Gordon, Marieka Klawitter. 2004. Discount Rates in Vietnam. Economic Development and Cultural Change 52:4, 873-887. [CrossRef]

145. Isabelle Brocas, Juan D. Carrillo. 2004. Entrepreneurial Boldness and Excessive Investment. Journal of Economics <btml_ent glyph="@amp;" ascii="ナramp;"/> Management Strategy 13:2, 321-350. [CrossRef]

146. Stefano DellaVigna, Ulrike Malmendier . 2004. Contract Design And Self-Control: Theory And Evidence*Contract Design And Self-Control: Theory And Evidence*. Quarterly Journal of Economics 119:2, 353-402. [Abstract] [PDF] [PDF Plus]

147. Lilia Maliar, Serguei Maliar. 2004. Quasi-geometric discounting: A closed-form solution under the exponential utility function. Bulletin of Economic Research 56:2, 201-206. [CrossRef]

148. Karen E. Dynan, Jonathan Skinner, Stephen P. Zeldes. 2004. Do the Rich Save More?. Journal of Political Economy 112:2, 397-444. [CrossRef]

149. Hugh Kelley. 2004. Measuring the Impact of Behavioral Traders on the Market for Closed-End Country Funds. Journal of Behavioral Finance 5:4, 201-213. [CrossRef]

150. Richard H. Thaler, Shlomo Benartzi. 2004. Save More Tomorrow ${ }^{\mathrm{TM}}$ : Using Behavioral Economics to Increase Employee Saving. Journal of Political Economy 112:S1, S164-S187. [CrossRef] 
151. Leonard Green, Joel Myerson. 2004. A Discounting Framework for Choice With Delayed and Probabilistic Rewards. Psychological Bulletin 130:5, 769-792. [CrossRef]

152. Faruk Gul, Wolfgang Pesendorfer. 2004. Self-Control and the Theory of Consumption. Econometrica 72:1, 119-158. [CrossRef]

153. Ariel Rubinstein. 2003. "Economics and Psychology"? The Case of Hyperbolic Discounting*. International Economic Review 44:4, 1207-1216. [CrossRef]

154. Pedro H. Albuquerque. 2003. A practical log-linear aggregation method with examples: heterogeneous income growth in the USA. Journal of Applied Econometrics 18:6, 665-678. [CrossRef]

155. George Loewenstein, Ted O'Donoghue, Matthew Rabin . 2003. Projection Bias In Predicting Future Utility*Projection Bias In Predicting Future Utility*. Quarterly Journal of Economics 118:4, 1209-1248. [Abstract] [PDF] [PDF Plus]

156. Erzo G. J. Luttmer, Thomas Mariotti. 2003. Subjective Discounting in an Exchange Economy. Journal of Political Economy 111:5, 959-989. [CrossRef]

157. David M Cutler, Edward L Glaeser, Jesse M Shapiro. 2003. Why Have Americans Become More Obese?. Journal of Economic Perspectives 17:3, 93-118. [CrossRef]

158. Colin Camerer, Richard H Thaler. 2003. In Honor of Matthew Rabin: Winner of the John Bates Clark Medal. Journal of Economic Perspectives 17:3, 159-176. [CrossRef]

159. Christopher D. Carroll , Karen E. Dynan , Spencer D. Krane . 2003. Unemployment Risk and Precautionary Wealth: Evidence from Households' Balance SheetsUnemployment Risk and Precautionary Wealth: Evidence from Households' Balance Sheets. Review of Economics and Statistics 85:3, 586-604. [Abstract] [PDF] [PDF Plus]

160. John Ameriks, Andrew Caplin , John Leahy . 2003. Wealth Accumulation and the Propensity to Plan*Wealth Accumulation and the Propensity to Plan*. Quarterly Journal of Economics 118:3, 1007-1047. [Abstract] [PDF] [PDF Plus]

161. James J Choi, David Laibson, Brigitte C Madrian, Andrew Metrick. 2003. Optimal Defaults. American Economic Review 93:2, 180-185. [CrossRef]

162. Ted O'Donoghue, Matthew Rabin. 2003. Studying Optimal Paternalism, Illustrated by a Model of Sin Taxes. American Economic Review 93:2, 186-191. [CrossRef]

163. Ayşe İmrohoroǧlu , Selahattin İmrohoroǧlu , Douglas H. Joines . 2003. Time-Inconsistent Preferences and Social Security*Time-Inconsistent Preferences and Social Security*. Quarterly Journal of Economics 118:2, 745-784. [Abstract] [PDF] [PDF Plus]

164. James P. Ziliak . 2003. Income Transfers and Assets of the PoorIncome Transfers and Assets of the Poor. Review of Economics and Statistics 85:1, 63-76. [Abstract] [PDF] [PDF Plus] 
165. Doron Sonsino, Uri Benzion, Galit Mador. 2002. The Complexity Effects on Choice with Uncertainty - Experimental Evidence*. The Economic Journal 112:482, 936-965. [CrossRef]

166. Roland Bénabou , Jean Tirole . 2002. Self-Confidence and Personal Motivation*Self-Confidence and Personal Motivation*. Quarterly Journal of Economics 117:3, 871-915. [Abstract] [PDF] [PDF Plus]

167. Shane Frederick, George Loewenstein, Ted O'donoghue. 2002. Time Discounting and Time Preference: A Critical Review. Journal of Economic Literature 40:2, 351-401. [CrossRef]

168. Kerwin Kofi Charles, Erik Hurst . 2002. The Transition to Home Ownership and the Black-White Wealth GapThe Transition to Home Ownership and the Black-White Wealth Gap. Review of Economics and Statistics 84:2, 281-297. [Abstract] [PDF] [PDF Plus]

169. Jonathan Gruber, Botond Köszegi . 2001. Is Addiction "Rational”? Theory and Evidence*Is Addiction "Rational"? Theory and Evidence*. Quarterly Journal of Economics 116:4, 1261-1303. [Abstract] [PDF] [PDF Plus]

170. Ted O'Donoghue, Matthew Rabin . 2001. Choice and Procrastination*Choice and Procrastination*. Quarterly Journal of Economics 116:1, 121-160. [Abstract] [PDF] [PDF Plus]

171. James E. Mazur. 2001. Hyperbolic value addition and general models of animal choice. Psychological Review 108:1, 96-112. [CrossRef]

172. Ted O'Donoghue, Matthew Rabin. 2000. The economics of immediate gratification. Journal of Behavioral Decision Making 13:2, 233-250. [CrossRef]

173. Peter H. M. P. Roelofsma, Daniel Read. 2000. Intransitive intertemporal choice. Journal of Behavioral Decision Making 13:2, 161-177. [CrossRef]

174. JAMES BANKS, CARL EMMERSON. 2000. Public and Private Pension Spending: Principles, Practice and the Need for Reform. Fiscal Studies 21:1, 1-63. [CrossRef]

175. Daniel Read, George Loewenstein, Shobana Kalyanaraman. 2000. Mixing virtue and vice: combining the immediacy effect and the diversification heuristic. Journal of Behavioral Decision Making 12:4, 257-273. [CrossRef]

176. Robert J. Barro . 1999. Ramsey Meets Laibson in The Neoclassical Growth Model *Ramsey Meets Laibson in The Neoclassical Growth Model *. Quarterly Journal of Economics 114:4, 1125-1152. [Abstract] [PDF] [PDF Plus]

177. Ted O'Donoghue, Matthew Rabin . 1999. Incentives For Procrastinators*Incentives For Procrastinators*. Quarterly Journal of Economics 114:3, 769-816. [Abstract] [PDF] [PDF Plus]

178. Colin Camerer. 1998. Bounded rationality in individual decision making. Experimental Economics 1:2, 163-183. [CrossRef]

179. John McHale6. Fiscal policy and the public finances: Creative approaches to pension funding 107-141. [CrossRef] 
180. Lisbeth Nielsen, John W.R. PhillipsHealth economic choices in old age: Interdisciplinary perspectives on economic decisions and the aging mind 227-270. [CrossRef]

181. Ming Hsu, Hung-Tai Lin, Paul E. McNamaraNeuroeconomics of decision-making in the aging brain: the example of long-term care 203-225. [CrossRef] 